\title{
Association mapping of drought tolerance and agronomic traits in rice (Oryza sativa L.) landraces
}

\author{
Radha Beena ${ }^{1 * \dagger}$, Silvas Kirubakaran ${ }^{2^{*}}$, Narayanan Nithya ${ }^{1 \dagger}$, Alagu Manickavelu ${ }^{3}$, Rameshwar Prasad Sah ${ }^{4}$, \\ Puthenpeedikal Salim Abida ${ }^{5}$, Janardanan Sreekumar ${ }^{6}$, Poolakkal Muhammed Jaslam ${ }^{7}$, Rajendrakumar Rejeth', \\ Vijayalayam Gengamma Jayalekshmy ${ }^{8}$, Stephen Roy ${ }^{1}$, Ramakrishnan Vimala Manju', Mariasoosai Mary Viji and \\ Kadambot H. M. Siddique ${ }^{9}$
}

\begin{abstract}
Background: Asian cultivars were predominantly represented in global rice panel selected for sequencing and to identify novel alleles for drought tolerance. Diverse genetic resources adapted to Indian subcontinent were not represented much in spite harboring useful alleles that could improve agronomic traits, stress resilience and productivity. These rice accessions are valuable genetic resource in developing rice varieties suited to different rice ecosystem that experiences varying drought stress level, and at different crop stages. A core collection of rice germplasm adapted to Southwestern Indian peninsular genotyped using SSR markers and characterized by contrasting water regimes to associate genomic regions for physiological, root traits and yield related traits. Genotyping-By-Sequencing of selected accessions within the diverse panel revealed haplotype variation in genic content within genomic regions mapped for physiological, morphological and root traits.
\end{abstract}

Results: Diverse rice panel (99 accessions) were evaluated in field and measurements on plant physiological, root traits and yield related traits were made over five different seasons experiencing varying drought stress intensity at different crop stages. Traits like chlorophyll stability index, leaf rolling, days to 50\% flowering, chlorophyll content, root volume and root biomass were identified as best predictors of grain yield under stress. Association mapping revealed genetic variation among accessions and revealed 14 genomic targets associated with different physiological, root and plant production traits. Certain accessions were found to have beneficial allele to improve traits, plant height, root length and spikelet fertility, that contribute to the grain yield under stress. Genomic characterization of eleven accessions revealed haplotype variation within key genomic targets on chromosomes 1, 4, 6 and 11 for potential use as molecular markers to combine drought avoidance and tolerance traits. Genes mined within the genomic QTL intervals identified were prioritized based on tissue specific expression level in publicly available rice transcriptome data.

Conclusion: The genetic and genomic resources identified will enable combining traits with agronomic value to optimize yield under stress and hasten trait introgression into elite cultivars. Alleles associated with plant height, specific leaf area, root length from PTB8 and spikelet fertility and grain weight from PTB26 can be harnessed in future rice breeding program.

\footnotetext{
*Correspondence: beena.r@kau.in; silvas.kirubakaran@basf.com

${ }^{\dagger}$ Radha Beena, Silvas Kirubakaran and Narayanan Nithya contributed

equally to this work.

${ }^{1}$ Department of Plant Physiology, College of Agriculture, Vellayani, Kerala

Agricultural University, Thiruvananthapuram, Kerala, India

2 BASF, Morrisville, NC 27560, USA

Full list of author information is available at the end of the article
} original author(s) and the source, provide a link to the Creative Commons licence, and indicate if changes were made. The images or other third party material in this article are included in the article's Creative Commons licence, unless indicated otherwise in a credit line to the material. If material is not included in the article's Creative Commons licence and your intended use is not permitted by statutory regulation or exceeds the permitted use, you will need to obtain permission directly from the copyright holder. To view a copy of this licence, visit http://creativecommons.org/licenses/by/4.0/. The Creative Commons Public Domain Dedication waiver (http://creativeco mmons.org/publicdomain/zero/1.0/) applies to the data made available in this article, unless otherwise stated in a credit line to the data. 


\section{Background}

Globally, rice (Oryza sativa L.) is a staple food grown in 144 million hectares span across 114 countries [1] to meet population explosion [2]. Global rice production was revolutionized after first green revolution with production increment of $140 \%$ by doubling of average productivity from 2.23 to $4.32 \mathrm{t} /$ ha [3]. However, increased production of about $60 \%$ is expected to meet future global needs [4]. Indian rice production is estimated to be 148.26 million metric tons from land area of 44.1 million hectares, in which one-half area is irrigated [5]. Drought stress is one of the major threat to the rice production in the Asian-Pacific region, affects yield stability in rainfed ecosystems [6]. Development of drought-resistant rice cultivars is critical to reduce climate-related risk, maintain productivity, and enhance livelihood of rice growers [7].

Drought tolerance consists of three major components involving interaction among physiological, morphological, biochemical traits [8]. The dehydration avoidance related traits maintain plant water status through enhanced root water uptake and reduced water loss in leaf through regulation of leaf area, stomatal conductance, canopy temperature and photosynthetic rate to result in high yield potential under water limitation. Leaf morphological, phenological, physiological and biochemical traits and their modulation is critical in maintaining plant water use and protect yield under water stress is well established in crop plants [9-17]. Roots are the first organ to experience water stress [18] and strongly associated with grain yield under stress $[15,19]$. Later, root traits were viewed as target traits to improve drought adaptation $[20,21]$ and regulate the canopy temperature through stomatal regulation [22]. The increase in yielding potential was observed by introgression of root trait [23]. Number of studies have been done to establish the relevance of root traits for water uptake [24-29] and their importance in yield protection under stress environments [22, 23, 30]. Efforts have been made to identify genomic regions associated with root traits in major cereal crops like rice [31], wheat [32] and legumes [33-36]. Drought adaptation and biomass productivity under stress depends on the plant Water Use Efficiency (WUE) or instantaneous WUE [37-39].

The success in developing drought tolerant germplasm achieved so far is attributed through choice of parents, selection criteria, and robustness of the managed screening protocols [40]. The future genetic improvements in rice productivity will be achieved by adapting holistic approach that integrates plant breeding with physiological dissection of resistance traits and molecular genetic/genomic tools together with agronomical management practices. Alternative to conventional mapping approach, selective genotyping was successfully utilized in rice breeding to map major QTLs for secondary traits $[10,13,24,41]$ and grain yield under stress [42]. Most of these Quantitative Trait Loci (QTLs) identified using bi-parental or multi-parental populations have limited the availability of allelic diversity and reduced genomic resolution for positional cloning process [43-46]. Genome Wide Association Study (GWAS) has emerged as a powerful approach to address limitations in traditional mapping approach and identify genes governing complex traits like rice root [47-52] and production traits [45, 53-55]. This approach has been successfully used to pinpoint root trait related genes associated with taproot cell length [56] and cortex cell properties [30].

To meet the global food demand, rich genetic diversity within both domestic and rice wild relatives should be explored towards genetic improvement of rice cultivars [57-59]. Brozynska et al. [60] reviewed the importance of crop wild relatives as a contributor of novel alleles to improve food security and stress adaptation [33, 34, 61-63]. Genome comparison among 3010 diverse accessions from Asia [64] exhibited huge divergence for novel alleles towards crop improvement. Local landraces and accessions from India are not widely represent in global rice panels $[65,66]$ in spite of useful genetic variation observed for various traits [10, 12, 13, 23-25]. The rice cultivars/accessions adapted to Southern India needs to be explored to identify novel genetic and genomic targets to improve stress resilience as Tamil Nadu and Kerala, are key rice target environments, highly affected by water limitation $[12,14,23$, 26]. The present study is conducted with the objectives, (1) Screen diverse rice accession adapted to target environment drought stress adaptive plant physiology, root and water use efficiency traits (2) Estimate genetic diversity, population structure and identify markertrait association and (3) Select parental genotypes with better phenotypic values towards developing rice cultivars with drought tolerance and productivity in water scarce environments.

\section{Results \\ Phenotypic variation for morpho-physiological and plant production traits in panel I}

Diverse rice accession within Panel I (Supplementary Table 1) exhibited significant variation for morphophysiological and plant production traits under water stress condition in trials 1 and 2 (Tables 1 and 2). The amount of precipitation and relative humidity observed in the trial sites are provided in Supplementary Figure 1. The effect of water stress is evident in trial II with higher 
percent change in leaf temperature $\left(6^{\circ} \mathrm{C}\right)$ than trial 1 with $3{ }^{\circ} \mathrm{C}$ resulted in reduction of plant height in trial 2 (5.35\%), in contrast to trial 1 with an average reduction of $4.58 \%$. Similar effect of water stress was observed for other production traits like days to $50 \%$ flowering, tiller number, yield per plant, and 1000-grain weight (Tables 1 and 2). Irrespective of the trials 1 and 2 under water stress treatment, PTB 7 produced higher tiller number with a range of 5 to 11 . The PTB55 and Prathyasha recorded the least and higher leaf rolling scores of 1.78 and 7.78, respectively. In dry season of trial 2, the PTB 27 was found to maintain higher plant water status, which is evident with higher relative water content of $73 \%$, than elite variety ADT37. PTB 35 recorded highest phenotypic values for yield per plant, 1000-grain weight through maintaining higher percent spikelet fertility traits in both trials. The relative yield reduction between rainfed and irrigated condition was lower in two accessions, Gopika

Table 1 Descriptive analysis of phenotypic, physiological and yield traits measured in Trial 1

\begin{tabular}{|c|c|c|c|c|c|c|}
\hline \multirow[t]{2}{*}{ Traits } & \multicolumn{2}{|l|}{ Mean } & \multicolumn{2}{|l|}{ Range } & \multirow{2}{*}{$\begin{array}{l}\text { Percentage } \\
\text { change }\end{array}$} & \multirow[t]{2}{*}{$P$-value } \\
\hline & WS & $\mathrm{C}$ & WS & C & & \\
\hline Plant height (cm) & $110.74 \pm 12.71$ & $116.05 \pm 12.78$ & $82.50-135.00$ & $87.50-144.10$ & -4.58 & 0.000251774 \\
\hline Tiller number & $7.53 \pm 1.22$ & $10.25 \pm 1.39$ & $5.00-11.00$ & $7.00-14.00$ & -26.54 & $2.04 \mathrm{E}-41$ \\
\hline Days to $50 \%$ flowering & $94.65 \pm 10.01$ & $88.47 \pm 10.81$ & $67.50-119.00$ & $61.50-114$ & 6.99 & $3.8 \mathrm{E}-07$ \\
\hline Leaf temperature $\left({ }^{\circ} \mathrm{C}\right)$ & $28.26 \pm 0.589$ & $27.50 \pm 0.533$ & $26.95-29.00$ & $26.00-29.35$ & 2.76 & $3.16 \mathrm{E}-27$ \\
\hline Leaf rolling score & $4.80 \pm 1.38$ & - & $1.78-7.78$ & - & - & \\
\hline Leaf drying score & 1.93 & - & $1.56-9.00$ & - & - & \\
\hline Relative water content (\%) & $65.19 \pm 4.78$ & $84.13 \pm 3.22$ & $57.34-78.72$ & $75.70-90.17$ & -22.51 & $1.3 \mathrm{E}-127$ \\
\hline Cell membrane stability index (\%) & $84.95 \pm 3.72$ & - & $80.28-94.36$ & - & - & - \\
\hline Chlorophyll stability index (\%) & $86.14 \pm 3.57$ & - & $80.36-95.59$ & - & - & - \\
\hline Yield/plant (g) & $9.55 \pm 1.89$ & $12.94 \pm 2.38$ & $6.55-14.47$ & $8.33-19.64$ & -26.20 & $1.05 E-34$ \\
\hline Thousand grain weight (g) & $22.71 \pm 1.48$ & $23.55 \pm 1.41$ & $17.55-25.35$ & $18.70-25.95$ & -3.57 & $5.71 \mathrm{E}-07$ \\
\hline Spikelet fertility percentage (\%) & $65.26 \pm 4.58$ & $75.43 \pm 4.75$ & $54.19-78.22$ & $64.96-86.91$ & -13.48 & $2 E-55$ \\
\hline Percentage relative yield reduction & $25.48 \pm 4.64$ & - & $14.84-43.81$ & - & - & - \\
\hline Drought susceptibility index & $1.00 \pm 0.062$ & - & $0.86-1.14$ & - & - & - \\
\hline Soil moisture (\%) & - & - & $12.4-30.96$ & - & - & - \\
\hline
\end{tabular}

WS water-stressed, C Irrigated condition

Table 2 Descriptive analysis of phenotypic, physiological and yield traits measured in Trial 2

\begin{tabular}{|c|c|c|c|c|c|c|}
\hline \multirow[t]{2}{*}{ Traits } & \multicolumn{2}{|l|}{ Mean } & \multicolumn{2}{|l|}{ Range } & \multirow{2}{*}{$\begin{array}{l}\text { Percentage } \\
\text { change }\end{array}$} & \multirow[t]{2}{*}{$P$-value } \\
\hline & WS & $C$ & WS & $C$ & & \\
\hline Plant height (cm) & $106.28 \pm 12.56$ & $112.29 \pm 12.28$ & $80.15-130$ & $86.50-140.50$ & -5.35 & $2.12 \mathrm{E}-05$ \\
\hline Tiller number & $6.34 \pm 0.845$ & $8.88 \pm 1.23$ & $5.00-8.50$ & $6.50-13.00$ & -28.60 & 7.87E-52 \\
\hline Days to $50 \%$ flowering & $91.26 \pm 10.86$ & $85.78 \pm 10.36$ & $65.50-115.50$ & $63.00-112.00$ & 6.38 & $6.58 \mathrm{E}-06$ \\
\hline Leaf temperature $\left({ }^{\circ} \mathrm{C}\right)$ & $29.56 \pm 0.548$ & $27.94 \pm 0.385$ & $27.30-30.55$ & $27.10-28.70$ & 5.79 & $6.78 \mathrm{E}-25$ \\
\hline Leaf rolling score & $4.05 \pm 1.39$ & - & $1.11-7.84$ & - & - & - \\
\hline Leaf drying score & $4.00 \pm 1.37$ & - & $1.17-7.67$ & - & - & - \\
\hline Relative water content (\%) & $61.07 \pm 4.79$ & $78.89 \pm 3.89$ & $50.35-72.98$ & $70.36-86.26$ & -22.58 & 7.4E-114 \\
\hline Cell membrane stability index (\%) & $81.83 \pm 3.70$ & - & $75.53-92.24$ & - & - & - \\
\hline Chlorophyll stability index (\%) & $82.11 \pm 3.85$ & - & $75.52-92.85$ & - & - & - \\
\hline Yield/plant (g) & $8.40 \pm 1.57$ & $11.55 \pm 2.15$ & $6.06-12.17$ & $7.94-18.62$ & -27.27 & $1.81 \mathrm{E}-37$ \\
\hline Thousand grain weight (g) & $21.78 \pm 1.33$ & $22.66 \pm 1.35$ & $17.15-24.00$ & $17.45-24.95$ & -3.88 & $3.16 \mathrm{E}-08$ \\
\hline Spikelet fertility percentage (\%) & $61.04 \pm 4.39$ & $70.91 \pm 4.58$ & $50.47-73.79$ & $61.12-81.93$ & -13.91 & $1.24 \mathrm{E}-55$ \\
\hline Percentage relative yield reduction & $29.46 \pm 4.96$ & - & $17.91-46.94$ & - & - & - \\
\hline Drought susceptibility index & $1.00 \pm 0.070$ & - & $0.75-1.17$ & - & - & - \\
\hline Soil moisture (\%) & - & - & $10.75-24.96$ & - & - & - \\
\hline
\end{tabular}


and Shreyas with a reduction of 15 and 18\%, respectively. These accessions also recorded lower drought susceptibility index of 1.14 and 1.17, whereas PTB25 exhibited lower DSI across trials. The association between grain yield, physiological and plant production traits in trial 1 and 2 are detailed in Supplementary Tables 2 and 3.

\section{Phenotypic diversity for root traits and water use in panel II}

The rainfed treatment of trial 3 and 4 received a total precipitation of 61 and $75 \mathrm{~mm}$, respectively spanning a growth period of June to September (Supplementary Figure 1). In spite of lower precipitation in trial 3, the diverse rice panel II exhibited higher average phenotypic value for $\mathrm{PH}(110.4 \mathrm{~cm})$, shoot biomass $(19.3 \mathrm{~g})$ and root biomass $(12.6 \mathrm{~g})$. Whereas in trial 4 recorded average phenotypic value for $\mathrm{PH}(108 \mathrm{~cm})$, shoot biomass $(18 \mathrm{~g})$ and root biomass $(5.5 \mathrm{~g})$ (Table 3$)$. To account for variation in the agro climatic condition across years (Trial 3 and 4), average phenotypic values across trials were calculated. In trials 3-4, lower CID values were observed in accessions, PTB7, PTB4, PTB8 and Kalladiyar, lower SLA [PTB26, 8, 54, 10, Kalladiyar, Chomala], average higher PH [PTB2, 10, 6, PTB 24, Thottacheera, Jeerakasala], Higher RL and RV [PTB1,2, 8, 10, 15, Chuvanna Modan, Kalladiyar], higher RB [PTB2, 10], and shoot biomass [PTB2, 10, 29), 26 and Kalladiyar].

\section{Relatedness among phenological, physiological and yield traits under stress}

In diverse panel I, the Principal Component Analysis (PCA) was performed for 14 morpho-physiological traits measured under water stress and well-watered conditions (Fig. 1). In Trial 1 water stress, the PCA revealed two principal components with Eigen values $>2$ capturing $58.3 \%$ of the total variation. The plots for the Principal Component $1(\mathrm{PC} 1)$ vs. $\mathrm{PC} 2$ represented a higher phenotypic variation of 41.8 , and $14.6 \%$. PC1 was greatly influenced by traits relative water content, cell membrane stability index, chlorophyll stability index, yield, spikelet fertility percentage, drought susceptibility index, leaf rolling and leaf drying. In Trial 2, 2018 water stress, the PCA revealed two principal components with Eigen values $>1$ capturing $52.7 \%$ of the total variation. The plots for the Principal Component 1 (PC1) vs. PC2 represented a higher phenotypic variation of $35.8 \%$, and 16.9. In Trial 2 , in addition to traits in Trial 1, plant height, tiller number, 1000-grain weight and relative yield ratio influenced PC1. Combining the data from trials 1 and 2, revealed two principal components with Eigen values $>3$ capturing $50.6 \%$ of the total variation. The plots for the Principal Component 1 (PC1) vs. $\mathrm{PC} 2$ represented a higher phenotypic variation of 39.3 , and $11.3 \%$. PC1 was greatly influenced by traits days to $50 \%$ flowering, drought
Table 3 Descriptive statistics of plant morphological, physiological and root traits measured in diverse panel II in trials 3 and 4

\begin{tabular}{llllll}
\hline Traits & Year & Min & Maximum & Mean & SD \\
\hline Plant Height (cm) & $\mathbf{2 0 1 1}$ & 62.90 & 174.40 & 110.36 & 24.67 \\
& $\mathbf{2 0 1 3}$ & 77.00 & 146.50 & 107.90 & 20.62 \\
& Average & 74.84 & 146.75 & 108.93 & 17.78 \\
SPAD-Chlorophyll content & $\mathbf{2 0 1 1}$ & 26.66 & 44.88 & 36.72 & 3.72 \\
(\%) & $\mathbf{2 0 1 3}$ & 27.20 & 40.60 & 34.45 & 3.19 \\
& Average & 29.22 & 41.03 & 35.62 & 2.50 \\
Shoot Biomass (g) & $\mathbf{2 0 1 1}$ & 4.08 & 29.24 & 19.26 & 7.32 \\
& $\mathbf{2 0 1 3}$ & 7.20 & 31.81 & 17.95 & 5.78 \\
& Average & 8.81 & 28.77 & 18.60 & 4.75 \\
Root Length (cm) & $\mathbf{2 0 1 1}$ & 27.40 & 90.60 & 40.97 & 10.56 \\
& $\mathbf{2 0 1 3}$ & 35.60 & 96.00 & 51.61 & 11.59 \\
& Average & 33.20 & 72.80 & 46.18 & 7.71 \\
Root Volume $\left(\mathrm{cm}^{3}\right)$ & $\mathbf{2 0 1 1}$ & 8.40 & 74.00 & 31.25 & 13.96 \\
& $\mathbf{2 0 1 3}$ & 13.30 & 90.00 & 37.40 & 18.73 \\
& Average & 14.50 & 78.00 & 34.20 & 12.54 \\
Root Biomass $(\mathrm{g})$ & $\mathbf{2 0 1 1}$ & 4.08 & 29.24 & 12.56 & 6.27 \\
& $\mathbf{2 0 1 3}$ & 1.70 & 13.83 & 5.54 & 2.49 \\
& Average & 4.08 & 18.19 & 9.04 & 3.25 \\
\hline & & & & &
\end{tabular}

susceptibility index, leaf temperature, spikelet fertility, relative water content and yield. Accessions PTB1, 4, $12,15,17,19,26,28,34,35,37,40,52,55,60$, Uma were found to have higher grain yield and spikelet fertility. The accessions, PTB 2,3,5,32,33,38,39,46,51,56,57, N-22, Sampada, Jeerakashala, Bhadra, Makom and Prathyasha were found to have alleles to improve DFF and DSI in rainfed condition.

To understand the relationship between significant phenological, physiological traits, root traits and shoot biomass measured in field trials 3 and 4, PCA was performed. The PCA revealed three principal components with Eigen values $>1$ capturing $60.6 \%$ of the total variation. The plots for the Principal Component 1(PC1) vs. PC2 represented a higher phenotypic variation (44.6\%), with 27.2 and $17.4 \%$, respectively. In 2011 study, PC1 was greatly influenced by traits SLA, RB, PH and SB. In 2013 study the PCA revealed three principal components with Eigen values $>1$ capturing $65.5 \%$ of the total variation. The plots for the Principal Component $1(\mathrm{PC} 1)$ vs. $\mathrm{PC} 2$ represented a higher phenotypic variation (52.0\%), with 35.6 and $16.4 \%$, respectively. Under both experimental conditions, the PC1 was greatly influenced by $\mathrm{PH}$ and $\mathrm{SB}$ whereas the $\mathrm{PC} 2$ is influenced by physiological and root traits. Correlation among average phenotypic values across years on $\mathrm{PH}, \mathrm{SDW}$, $\mathrm{RV}, \mathrm{RL}$ and RDW revealed plant height to be significantly associated with shoot biomass, root volume, and 


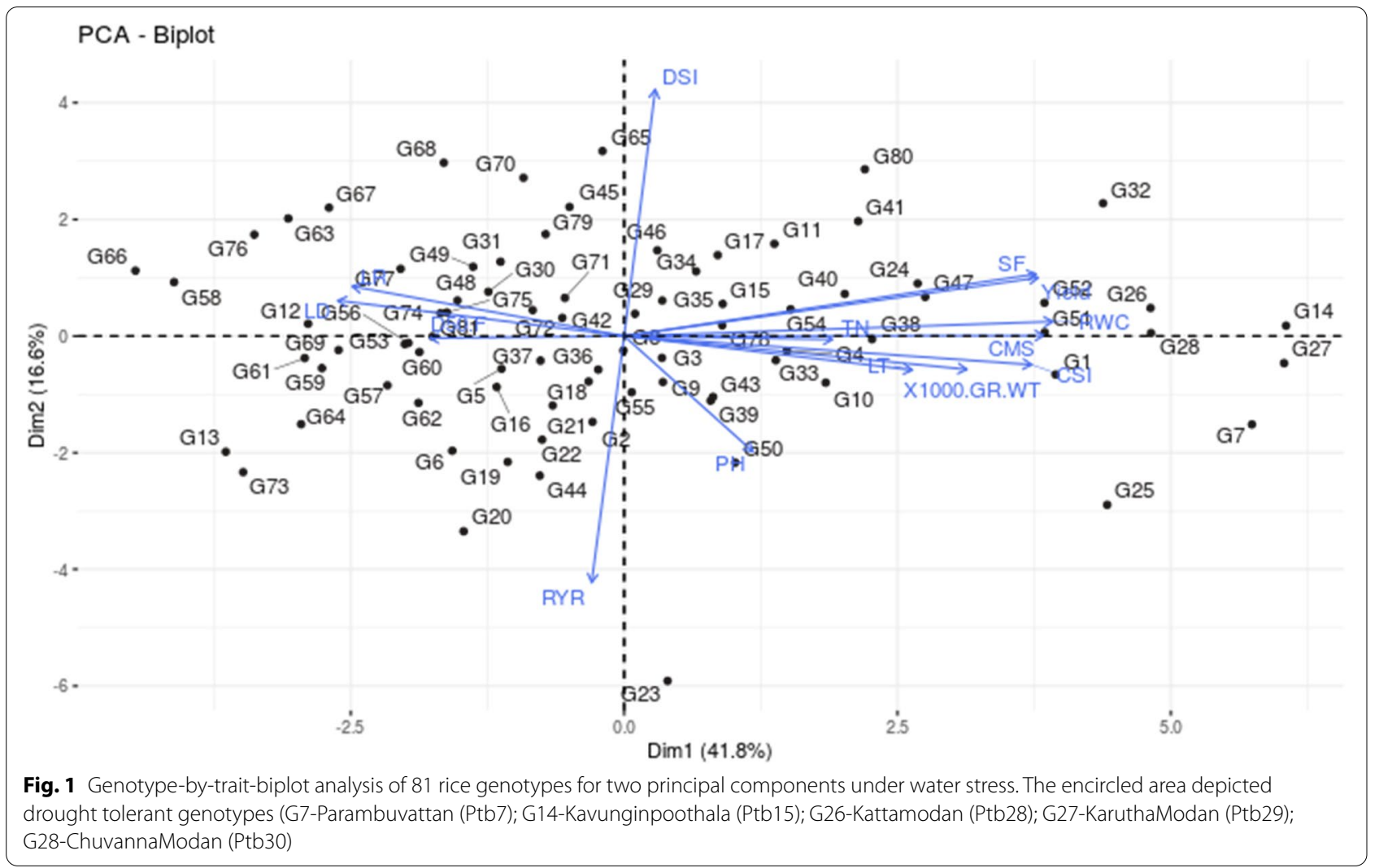

root biomass (Supplementary Table 4). The root traits, RL and RV are associated with both shoot and root biomass. The physiological traits, canopy temperature is positively correlated to plant height, negatively correlated to SPAD chlorophyll content and carbon isotope discrimination values measured.

\section{Predictors of grain yield in different drought stress intensity}

Average data of 63 rice common accessions between trials 1 to 4 were used to identify traits that are good predictors of yield (Trial 1 and 2) and shoot biomass (Trials 3 and 4). The RWC, 1000GW, SF, CMS, CSI are determined to be best predictors of average grain yield in Trial 1 and 2. Shoot biomass is directly associated with grain yield under rainfed rice ecosystems. The average data on RB, RV, SPAD (trials 3 and 4), LT and RYR (Trials 1 and 2) were best predictors of shoot biomass measured. To identify the grain yield predictors under different intensity of drought stress imposed on trials 1, 2 and 5, average data on 35 accessions common across trials were analyzed. This analysis revealed CSI (Trials 1 and 2), LR (trial 5), DFF (Trials 1 and 2), Chlorophyll content (Trial 2), RV (Trials 3 and 4) and RB (Trials 3 and 4) were found to best predictors of grain yield under water stress condition in trial 5 . Clustering of the 35 diverse accessions across trials 1-5 based on average RV and RB revealed 4 different clusters with four rice accessions [PTB1, 2,10 and 13] with higher average phenotypic value for RV and RB. Within this cluster, the accessions, PTB1,2, and 10 was found to be high yielding in trial $1-2,4$ and 5 , also possess valuable alleles for root architectural traits. The average yield of PTB1 is $12 \mathrm{~g}$, whereas $\mathrm{N} 22$ rice cultivar is only $7.2 \mathrm{~g}$ in Trials $1-2$, whereas in trial 5 , the average shoot biomass of landrace, Ponnaryan (PTB2) across years is $27.6 \mathrm{~g}$, which is on par to rice hybrid, PHB71 (28.6g), and better than $\mathrm{N} 22$, a known rice cultivar to be drought and heat tolerant with $20.3 \mathrm{~g}$.

\section{Genotypic relatedness of diverse accession panels}

Genetic related analysis of Panel I revealed nine different clusters, including seven clusters only with local rice landraces harbor valuable alleles to improve different agronomic traits in rice lines adapted to rainfed ecosystem. Interestingly, Aryan (PTB1) and PTB10 (Thekkancheera) are genetically closer, whereas accession, PTB2 (Ponnaryan) is genetically dissimilar to any high yielding cultivars evaluated in this study. To illustrate the genetic relatedness among diverse rice lines of Panel II, Principal coordinate analysis (PCoA) was performed (Fig. 2) reveled four quadrants with 56, 4, 


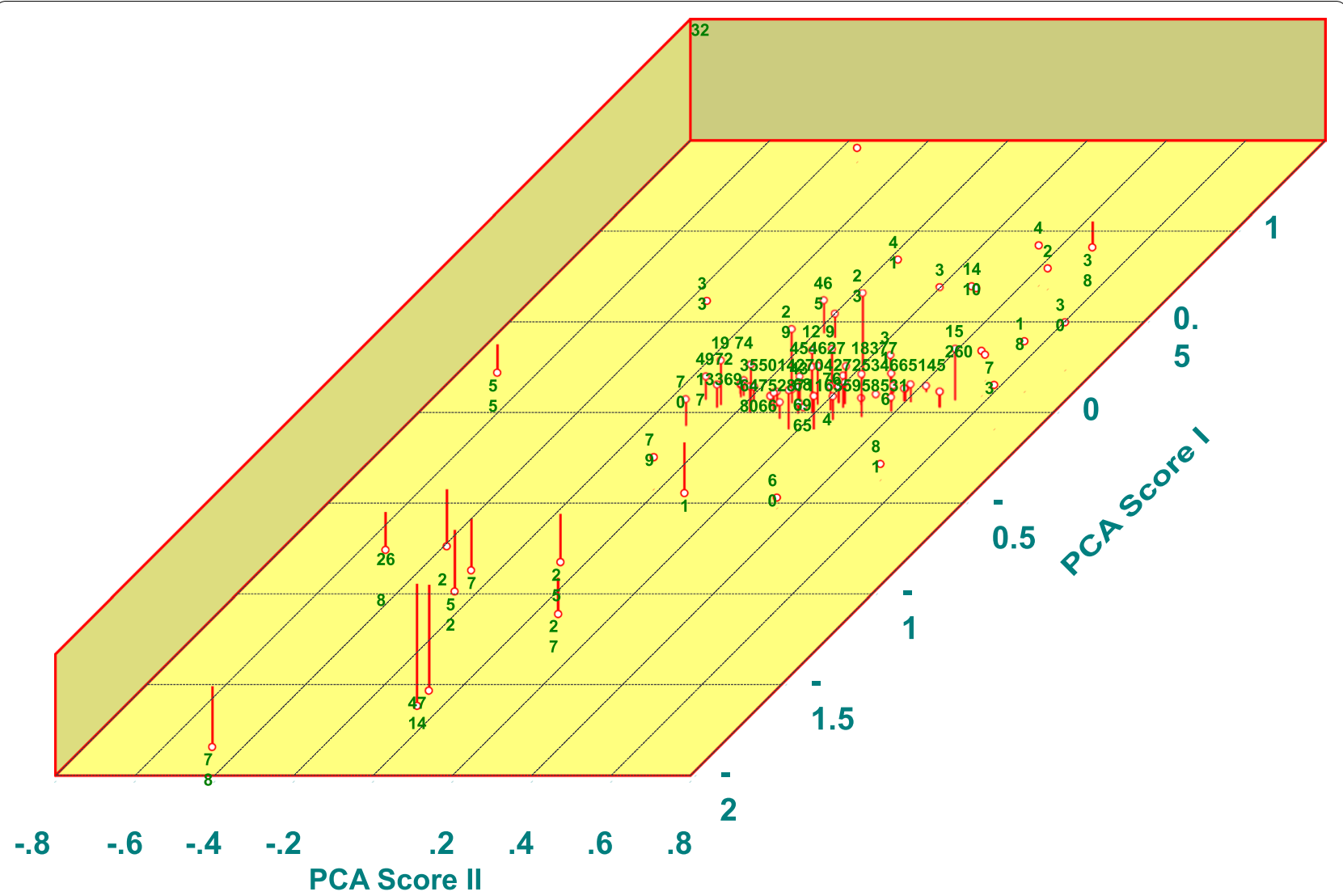

Fig. 2 Three dimensional of Principal Co-ordinate analysis of 81 rice diverse panel II genotyped with 100 Simple Sequence Repeat markers

8 and 13 genotypes, respectively. The fourth quadrant is a mixture with a pool of rice accessions with known drought tolerance [PTB30 (ChuvannaModan)], and other agronomic traits [PTB 20,33, 34, 47, 56, Gandhakasala, Sampada]. To gain more insights on the diversity and relatedness among diverse accessions, a hierarchical clustering was performed to derive a phylogenetic analysis representing seven clusters. Further mining of diverse accessions within in fourth quadrant, revealed PTB30 (Chuvanna Modan), PTB20 (Vadakkan Chitteni), PTB47 (Neeraja), PTB34 (Valiya Champan) are genetically similar than other accessions, Gandhakasala, PTB56 (Varsha), PTB33 (Arikkirai), and Sampada. PCA of marker data revealed a cluster with accession Ponnaryan with higher yield under stress and root architectural traits, is genetically similar to Vellari (Fig. 3).

\section{Population structure and linkage disequilibrium analysis}

Population structure analysis among 81 rice genotypes with a set of 100 SSR markers determined optimum $\mathrm{K}$ value of two, representing the diverse panel group into two major clusters (Fig. 4). In Panel I, first cluster comprised 65 genotypes and the second cluster with 16 genotypes including 6 admixture accessions. In Panel II, the first cluster comprised known to include drought susceptible genotypes but high yielding genotypes suited to irrigated condition, whereas the second cluster comprised known drought tolerant genotype, Nagina-22. Certain genotypes in cluster 2 had higher average phenotypic values across years than known drought tolerant genotype Nagina-22 for PH and SPAD [PTB28], RL [PTB1, 34 and Sabari), RV (genotypes in cluster 2), RB (PTB1) and SB (PTB60-Vaishak).

The linkage disequilibrium (LD) map of the diverse panel (Panel I and II) revealed $8.25 \%$ of 100 SSR markers studied exhibited an $\mathrm{R} 2$ value of $\geq 0.1$. In Panel $\mathrm{I}$, the LD was unevenly distributed at genome level and concentrated on chromosomes 1 and 5. Among 52 LD hotspots identified, includes 46 inter-chromosomal LD pairs and 6 intra chromosomal LD pairs. LD plots with SSR markers demonstrated significant LD blocks are shown in Fig. 5. In Panel II, the LD was not uniform across the genome, higher LD values were observed on chromosomes $1,2,6$, and 9 with 49 LD pairs spanning genomic regions. 


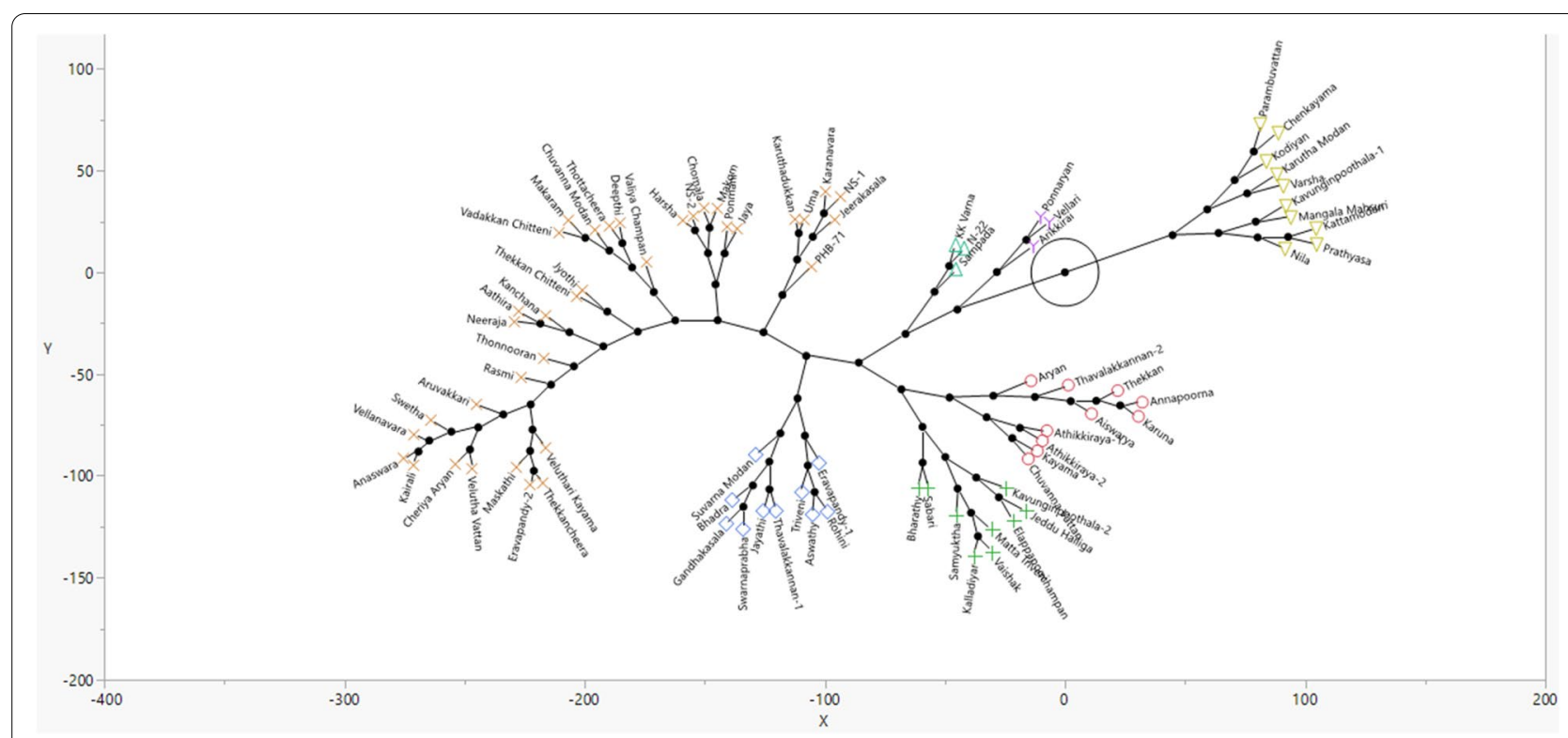

Fig. 3 Constellation plot to show genetic relatedness among 81 diverse rice of Panel II based on hierarchial clustering analysis

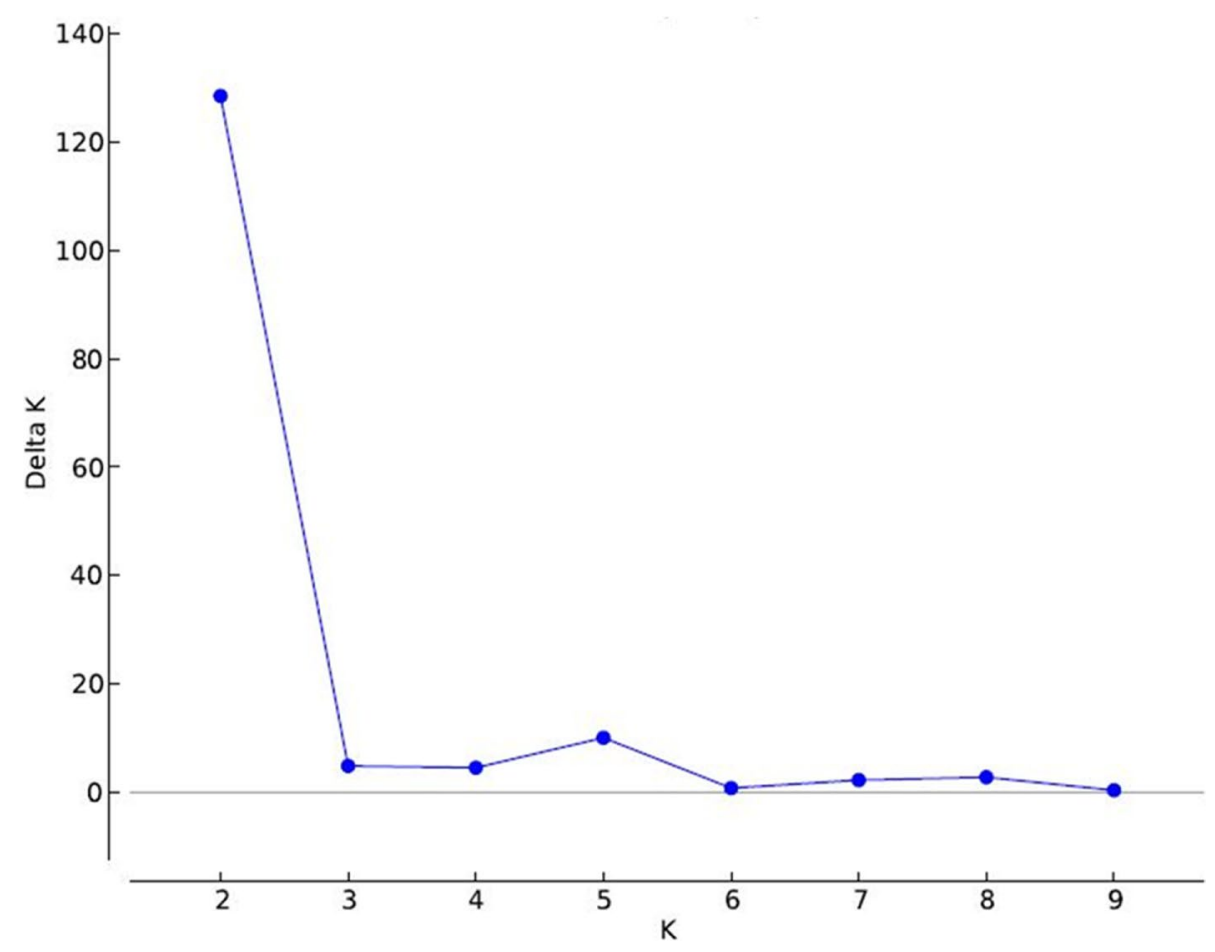

Fig. 4 Estimates of subpopulations analysis of 81 diverse rice panels revealed 2 sub population using delta K-values with STRUCTURE program

\section{Mapping genomic regions with association analysis}

The marker-trait associations for the phenotypic traits measured in diverse Panels I and II. In Panel I, the marker trait associations with GLM and MLM approaches identified 83 (Supplementary Table 5) and 16 (Table 4) significant loci, respectively. Especially the loci on chromosome 1, RM490 associated with CMS, CSI, RM259 associated with RWC, LR, LD, CMS, CSI, 


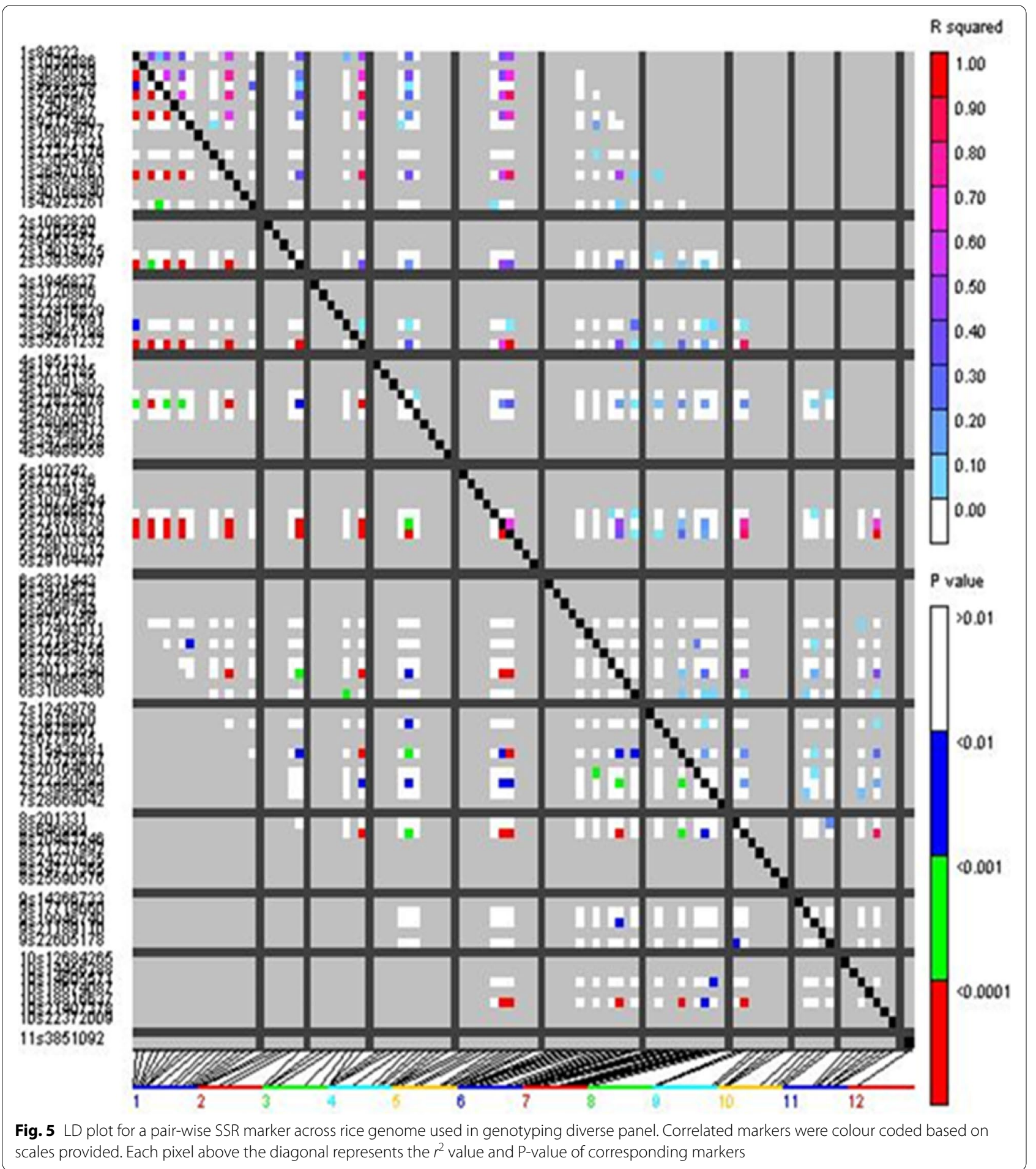

and SF identified with GLM approach, was identified by MLM approach. The loci, RM3825 on chromosome 1 associated with LT, RWC, CMS, CSI, Yield, 1000-GW, and SF (GLM) was detected in MLM approach with association with yield per plant.
In Panel II, the GLM approach detected 33 genomic regions associated with eight traits across genome except chromosomes 3 and 5 (Supplementary Table 6) with phenotypic variation ranging from 4.8 to $15.9 \%$. The MLM approach detected 21 genomic regions 
Table 4 Marker trait association identified with MLM analysis in diverse panel I phenotypic data measured under water stress

\begin{tabular}{|c|c|c|c|c|}
\hline Traits & Marker associated & Chromosome & $P$ value & $r^{2}$ value \\
\hline \multirow[t]{2}{*}{ Leaf temperature $\left({ }^{\circ} \mathrm{C}\right)$} & RM490 & 1 & 0.04996 & 0.05192 \\
\hline & RM259 & 1 & 0.02398 & 0.06945 \\
\hline \multirow[t]{2}{*}{ Chlorophyll stability index (\%) } & RM490 & 1 & 0.00736 & 0.07886 \\
\hline & RM259 & 1 & 0.00775 & 0.07778 \\
\hline \multirow[t]{2}{*}{ Yield per plant (g) } & RM259 & 1 & 0.02936 & 0.06402 \\
\hline & RM3825 & 1 & 0.02105 & 0.07209 \\
\hline Thousand grain weight (g) & RM5961 & 11 & 0.0312 & 0.05483 \\
\hline \multirow[t]{2}{*}{ Spikelet fertility (\%) } & RM259 & 1 & 0.0098 & 0.07782 \\
\hline & RM1031 & 6 & 0.04376 & 0.04657 \\
\hline Leaf rolling score & RM1026 & 9 & 0.00386 & 0.10547 \\
\hline \multirow[t]{2}{*}{ Leaf drying score } & RM259 & 1 & 0.03024 & 0.05067 \\
\hline & RM1026 & 9 & 0.01671 & 0.06224 \\
\hline \multirow[t]{2}{*}{ Relative yield reduction (\%) } & RM5633 & 4 & 0.04017 & 0.05729 \\
\hline & RM1130 & 6 & 0.01309 & 0.08492 \\
\hline \multirow[t]{2}{*}{ Drought susceptibility index } & RM5633 & 4 & 0.04094 & 0.05682 \\
\hline & RM1130 & 6 & 0.01345 & 0.08419 \\
\hline
\end{tabular}

(Table 5) associated with nine physiological and root architectural traits measured. Three new genomic regions that were not detected in GLM approach were identified with MLM approach. Three regions, RM283 (Chr.1), RM474 (Chr.10), RM5923 (Chr.11) were found only in MLM approach to be associated with SLA, SDW and RDW respectively. For example, the region RM1032 on chromosome 1 associated with plant height and root length, RM5961 on chromosome 11 was found to be associated with PH, CID and SLA.

Table 5 Marker trait association identified with MLM analysis in diverse panel II phenotypic data measured under water stress

\begin{tabular}{|c|c|c|c|c|}
\hline Trait & Marker associated & Chromosome number & $p$-value & $r^{2}$ value \\
\hline \multirow[t]{2}{*}{ Plant Height (cm) } & RM1032 & 1 & 0.02369 & 0.06739 \\
\hline & RM5961 & 11 & 0.0272 & 0.06414 \\
\hline \multirow[t]{3}{*}{ Root Length (cm) } & RM1048 & 7 & 0.01914 & 0.07245 \\
\hline & RM1019 & 8 & 0.02792 & 0.06353 \\
\hline & RM1032 & 1 & 0.03786 & 0.05648 \\
\hline \multirow[t]{3}{*}{ Root Volume $\left(\mathrm{cm}^{3}\right)$} & RM5715 & 12 & 0.01405 & 0.07992 \\
\hline & RM1178 & 2 & 0.01452 & 0.07911 \\
\hline & RM246 & 1 & 0.03366 & 0.05918 \\
\hline Root dry weight (g) & RM5923 & 11 & 0.04139 & 0.05444 \\
\hline \multirow[t]{2}{*}{ Shoot dry weight (g) } & RM1178 & 2 & 0.00507 & 0.10531 \\
\hline & RM474 & 10 & 0.03569 & 0.05783 \\
\hline \multirow[t]{2}{*}{ SCMR- Chlorophyll content (\%) } & RM5633 & 4 & 0.03022 & 0.06169 \\
\hline & RM1178 & 2 & 0.03806 & 0.05636 \\
\hline \multirow[t]{3}{*}{ Chlorophyll content } & RM1026 & 9 & 0.01678 & 0.07561 \\
\hline & RM259 & 1 & 0.03092 & 0.06115 \\
\hline & RM5633 & 4 & 0.04763 & 0.05126 \\
\hline \multirow[t]{2}{*}{ Carbon isotope discrimination $\left(\Delta^{13} \mathrm{C}\right)$ ratio } & RM5961 & 11 & 0.01652 & 0.07598 \\
\hline & RM1019 & 8 & 0.01918 & 0.07241 \\
\hline \multirow[t]{3}{*}{ Specific leaf area $\left(\mathrm{cm}^{2}\right)$} & RM5961 & 11 & 0.01369 & 0.08054 \\
\hline & RM5633 & 4 & 0.02136 & 0.06984 \\
\hline & RM283 & 1 & 0.04124 & 0.05453 \\
\hline
\end{tabular}




\section{Co-location of QTLs with known drought related traits in rice}

Especially the genomic regions detected in Panel II with majority of rice landraces on chromosome 1 (RM246), 7 (RM1048), 9 (RM1026), and 12 (RM5715) governing both physiological and root structure under water limitation are valuable genomic targets for rice trait breeding approach. The RM246 QTL was found to be linked with submergence [68], salinity tolerance [67], root biomass, basal root thickness [68] and yield [69, 70]. The RM1048 QTL was found to be linked with plant height [71], panicle length [72], leaf rolling [73] and cold tolerance [74]. The common regions, RM1026 and RM5961 detected in both panels co-locate QTLs for tiller number [66], biomass and grain yield [75], respectively.

\section{Tissue specific expression of genes underlying major QTL regions}

Based on the physical position of markers associated with key traits, genes underlying QTLs identified were tabulated (Tables 6 and 7). In Panel I, eight loci on chromosomes 1, 4, 6, 9 and 11 flanking eleven genes were identified (Table 6). Among 11 genes, only 9 genes exhibited expression in Affymetrix datasets whereas all genes showed expression pattern in RNA-transcriptome.
Among 13 genes identified in Panel II (Table 7), 10 genes exhibited tissue specific expression in rice grown in nonstress conditions.

In Panel I, four genomic regions, RM490, RM3825 (chromosome 1), RM1130 and RM1031 (chromosome 6) were not detected in Panel II. The peptidase C45 gene (LOC_Os01g12230) associated with chlorophyll stability index was highly expressed in flag leaf in Affymetrix [76] and transcriptome study [77]. Between two loci underlying genomic region RM3825, the Ras-related protein (LOC_Os01g62950) exhibited higher expression in pollen [78] and anther [79]. The gene, DNA binding protein (LOC_Os06g45110) associated with RYR and DSI showed higher expression in root tip [80] specially in root elongation zone [81]. The expressed protein encoding gene, LOC_Os06g51330 exhibited higher expression of 14 fold in sperm cell [78] and callus [82].

Between Panel I and II, interestingly four locus (RM259, RM5633, RM1026 and RM5961) harboring five genes (LOC_Os01g13360, LOC_Os04g23030, LOC_ Os04g23040, LOC_Os09g39320 and LOC_Os11g34070) were common and identified to be linked to key plant physiological production traits in rice. Gene expression analysis revealed the gene (LOC_Os01g09550) associated with SLA to be highly expressed in internode of rice dwarf

Table 6 Genes underlying common genomic regions identified in marker trait association in diverse panel I

\begin{tabular}{|c|c|c|c|c|c|}
\hline \multirow[t]{2}{*}{ Marker } & \multirow[t]{2}{*}{ Chr. } & \multirow[t]{2}{*}{ Physical position (Mb) $^{a}$} & \multicolumn{2}{|l|}{ Traits associated } & \multirow[t]{2}{*}{ Genes within confidence interval $^{a}$} \\
\hline & & & GLM & MLM & \\
\hline RM259 & 1 & $7446642 . .7446813$ & CSI, SF, LD, LR, RWC & $\begin{array}{l}\text { LT, CSI, SF, LD, Yield } \\
\text { per plant }\end{array}$ & $\begin{array}{l}\text { Phosphatidylinositol 3- and 4-kinase } \\
\text { family protein } \\
\text { LOC_Os01g13360 }\end{array}$ \\
\hline RM490 & 1 & $6677153 . .6677249$ & CSI, CMS & $\mathrm{LT}, \mathrm{CSI}$ & $\begin{array}{l}\text { peptidase C } 45 \\
\text { LOC_Os01g12230 } \\
\text { Hypothetical protein } \\
\text { LOC_Os01g12240 }\end{array}$ \\
\hline $\mathrm{RM} 3825$ & 1 & $36471204 . .36471354$ & $\begin{array}{l}\text { LT, RWC, CMS, CSI, SF, } \\
\text { 1000GW, Yield per plant }\end{array}$ & Yield per plant & $\begin{array}{l}\text { Ras-related protein } \\
\text { LOC_Os01g62950 } \\
\text { Hypothetical protein } \\
\text { LOC_Os01g62960 }\end{array}$ \\
\hline RM5633 & 4 & $13084092 . .13084302$ & $\mathrm{PH}, \mathrm{DFF}$ & DSI, RYR & $\begin{array}{l}\text { Retrotransposon protein } \\
\text { LOC_Os04g23030 } \\
\text { Expressed protein } \\
\text { LOC_Os04g23040 }\end{array}$ \\
\hline RM1130 & 6 & $27284878 . .27285006$ & - & DSI, RYR & $\begin{array}{l}\text { DNA binding protein } \\
\text { LOC_Os06g } 45110\end{array}$ \\
\hline RM1031 & 6 & $31083106 . .31089543$ & CMS, RWC & SF & $\begin{array}{l}\text { Expressed protein } \\
\text { LOC_Os06g51330 }\end{array}$ \\
\hline RM1026 & 9 & $22605659 . .22605822$ & $\mathrm{PH}$ & $L R, L D$ & $\begin{array}{l}\text { CTR1-like protein kinase } \\
\text { LOC_Os09g39320 }\end{array}$ \\
\hline RM5961 & 11 & $19926656 . .19926784$ & - & 1000GW & $\begin{array}{l}\text { Hypothetical protein } \\
\text { LOC_Os11g34070 }\end{array}$ \\
\hline
\end{tabular}

Abbreviations: CMS Chlorophyll Membrane Stability, CSI Chlorophyll Stability Index, DSI Drought susceptibility index, LD Leaf Drying, LR Leaf Rolling, LT Leaf Temperature, RWC Relative Water Content, RYR Relative Yield Ratio, SF Spikelet Fertility, 1000GW Thousand grain weight

a The physical position of SSR markers and genes underlying were obtained from www.ricebase.org 
Table 7 List of genes underlying genomic regions identified in both GLM and MLM approaches with association analysis in diverse panel II

\begin{tabular}{|c|c|c|c|c|c|}
\hline \multirow[t]{2}{*}{ Marker } & \multirow[t]{2}{*}{ Chr. } & \multirow[t]{2}{*}{ Physical position (Mb) ${ }^{a}$} & \multicolumn{2}{|c|}{ Traits associated } & \multirow[t]{2}{*}{ Genes within confidence interval $^{a}$} \\
\hline & & & GLM & MLM & \\
\hline RM259 & 1 & $7446642-7446813$ & Chl & Chl & $\begin{array}{l}\text { Phosphatidylinositol 3- and 4-kinase family protein } \\
\text { (LOC_Os01g13360) }\end{array}$ \\
\hline RM1032 & 1 & $9318464-9318612$ & $\mathrm{PH}, \mathrm{RL}$ & $\mathrm{PH}, \mathrm{RL}$ & $\begin{array}{l}\text { NB-ARC domain (LOC_Os01g16400) } \\
\text { Actin (LOC_Os01g16414) }\end{array}$ \\
\hline RM246 & 1 & $27336221-27336333$ & SPAD & RV & CS domain containing protein ( $\mathrm{LOC} \_$Os01g47770) \\
\hline RM1178 & 2 & $14020245-14020356$ & $\mathrm{RV}, \mathrm{SDW}, \mathrm{CT}$ & RV, SDW, SPAD & Expressed protein (LOC_Os02g24205) \\
\hline RM5633 & 4 & $13084092-13084302$ & $\mathrm{RL}, \mathrm{RV}$ & SPAD, Chl, SLA & $\begin{array}{l}\text { Retrotransposon protein (LOC_Os04g23030) } \\
\text { Expressed protein (LOC_Os04g23040) }\end{array}$ \\
\hline RM1048 & 7 & $20165312-20165449$ & $\mathrm{RL}, \mathrm{CT}$ & $\mathrm{RL}$ & NB-ARC domain (LOC_Os07g33730 \\
\hline RM1019 & 8 & $202331-202477$ & $\mathrm{RL}, \mathrm{SPAD}, \mathrm{Chl}$ & $\mathrm{RL}, \mathrm{CID}$ & Broad Complex BTB domain (LOC_Os08g01320) \\
\hline RM1026 & 9 & $22605659-22605822$ & $\mathrm{RL}, \mathrm{RV}, \mathrm{Chl}$ & $\mathrm{Chl}$ & CTR1-like protein kinase (LOC_Os09g39320) \\
\hline RM5961 & 11 & $19926656-19926784$ & Chl & $\mathrm{PH}, \mathrm{CID}, \mathrm{SLA}$ & Hypothetical protein (LOC_Os11g34070) \\
\hline RM5715 & 12 & $25034080-25034280$ & $\mathrm{RV}, \mathrm{RL}, \mathrm{Chl}$ & RV & $\begin{array}{l}\text { Biotin--protein ligase (LOC_Os12g40450) } \\
\text { C3HC4 type domain protein (LOC_Os12g40460) }\end{array}$ \\
\hline
\end{tabular}

Abbreviations: Ch/ Chlorophyll content, PH Plant Height, RL Root length, RV Root Volume, SPAD Chlorophyll content (\%), SDW Shoot Dry Weight, CT Canopy Temperature, SLA Specific Leaf Area, CID Carbon Isotope Discrimination

a The physical position of SSR markers and genes underlying were obtained from www.ricebase.org

mutant Fukei71 [83], treatment with gibberellin [84] and brassinosteroid [85]. The loci RM259 associated with chlorophyll content underlying gene, LOC_Os01g13360 was found to highly express in endosperm [86] and caryopsis [87]. The Loci, LOC_Os01g16400 associated with RL was found to highly expressed in root tip [88] and LOC_Os01g16414 associated with PH was highly expressed in shoot apex [87] and embryogenesis (PRJNA412710). The locus, LOC_Os04g23040 associated with SPAD, Chl, SLA on MLM approach was found to be highly expressed in flag leaves in both seedling and grain filling stages $[77,89]$ and leaf blade tissues [84, 90]. LOC_Os08g01320 associated with RL, SPAD, Chl (GLM approach) and RL, CID (MLM approach) was found to highly express in flag leaf [89], leaf blade (PRJNA392837) and root tissues (GSE24977). LOC_Os12g40460 associated with RV in both approaches were highly expressed in radicle tissue $[91,92]$.

Tissue specific expression data from global RNA transcriptome datasets revealed some genes not represented in Affymetrix arrays like, LOC_Os02g24205 associated with RV and SDW to be highly expressed in anther and pollen tissues [79], LOC_Os07g33730 associated with RL expressed in callus tissues [82]. The locus, LOC_ Os09g39320 associated with chlorophyll content was found to highly express in flag leaf [77]. The genes, biotin--protein ligase (LOC_Os12g40450) and zinc finger, C3HC4 type domain protein (LOC_Os12g40460) associated with root volume was found to highly expressed in rice callus [82] and embryo [93].

\section{Genes underlying major QTL regions associated with drought stress}

In Panel I, analysis of 11 genes with stress transcriptome datasets revealed six genes (LOC_Os01g12230, LOC_ Os01g62950, LOC_Os04g23040, LOC_Os06g45110, LOC_Os06g51330, LOC_Os09g39320) to be highly expressed in rice tissues. The LOC_Os01g12230 (CSI), LOC_Os04g23040 (DSI, RYR) and LOC_Os06g51330 (SF) were highly expressed in leaf tissues under drought [94]. Intriguingly, the LOC_Os01g62950 (yield per plant), LOC_Os06g45110 (DSI and RYR) and LOC_Os09g39320 (LR, LD) were found to be highly expressed in 4 week old seedling root tissues under drought [95].

In Panel II, evaluation of rice stress related gene expression datasets revealed LOC_Os01g09550 and LOC_Os01g16414 associated with SLA and PH to highly express in leaf tissue and panicle under stress [96]. These similar loci exhibited higher expression in rice root transcriptome study [95] and in leaf tissues under drought (PRJNA306542). The locus, LOC_ Os04g23040 associated with different leaf traits was found to highly expressed in flag leaf [97] and other leaves under drought [94, 96, 98]. LOC_Os08g01320 associated with above and below ground root traits were found highly expressed in both flag leaf and root tissues under drought [94, 95, 97, 99]. LOC_ Os12g40460 associated with RV in both mapping approaches, showed higher expression in root tissues under drought [100]. Drought stress specific global RNA transcriptome datasets revealed certain genes 
like LOC_Os02g24205 to be highly expressed in leaf in drought stress studies in rice [94, 98]. Whereas the locus, LOC_Os07g33730 associated with RL was found to be highly expressed in root tissues under drought [95]. The locus, LOC_Os09g39320 associated with root traits and chlorophyll content was found to highly expressed both roots and leaf tissues (Fig. 6) under drought $[94,95,98]$. Among two genes near the locus RM5715, biotin-protein ligase (LOC_Os12g40450) associated with root volume showed higher expression in root tissues (Fig. 6) under drought stress [95].

\section{Gene targets and SNP haplotype variation for trait introgression}

Allele mining approach was employed with GBS data of selected 11 accessions (9 landraces [Chenkazhama; PTB26, Cholmala, Gandhakasala, Jeerakasala, Kalladiyar, Ponnaryan; PTB2, Thavalakannan; PTB8, Thekkan Cheera; PTB10 and Thonnuran] and 2 improved varieties [Athira; PTB51 and Jaya]) from a previous published literature [101]. Field trials in this study revealed these 9 landrace accessions to have desired phenotypic variances in Trials 1-4 than two improved varieties. Comparing four field trials, PTB2 recorded higher CSI (trials 1 and 2), PH, RL, RV, RB and Shoot biomass (trials 3 and 4). PTB8 was identified to be possess higher phenotypic variation for grain yield, CSI (trials 1 and 2), whereas for PH, CID, SLA and Root traits (RL, RV) in trials 3 and 4. PTB10 also recorded lower LR and LD, higher 1000GW, and yield, whereas this accession exhibited lower SLA, PH, root traits (RL, RV and RB) and shoot biomass in trials 3 and 4 . PTB25 recorded lower LR and LD, DSI values, higher 1000 GW (trials 1 and 2) and higher shoot biomass (trials 3 and 4). In trials 1 and 2, PTB26 recorded higher SF and seed yield, whereas exhibited higher $\mathrm{PH}$ and shoot biomass in trials 3 and 4. Jeerakasala recorded lower RYR (trials 1 and 2) and higher PH (trials 3 and 4). Gandhakashala recorded lower DFF (trials 1 and 2) and CT than elite varieties, Jaya and PTB 51. Kalladiyar is an accession evaluated only in trials 3 and 4, found to have lower CID, lower SLA, higher RL and RV and shoot biomass.

Sequence level variation between Oryza sativa ssp. Indica reference genome to 93 local landraces from Kerala, revealed alternative haplotypes in key genomic regions identified in this study (Table 8). Further a deletion of sequence 'ACCATCCATC' (9318232Mb) was

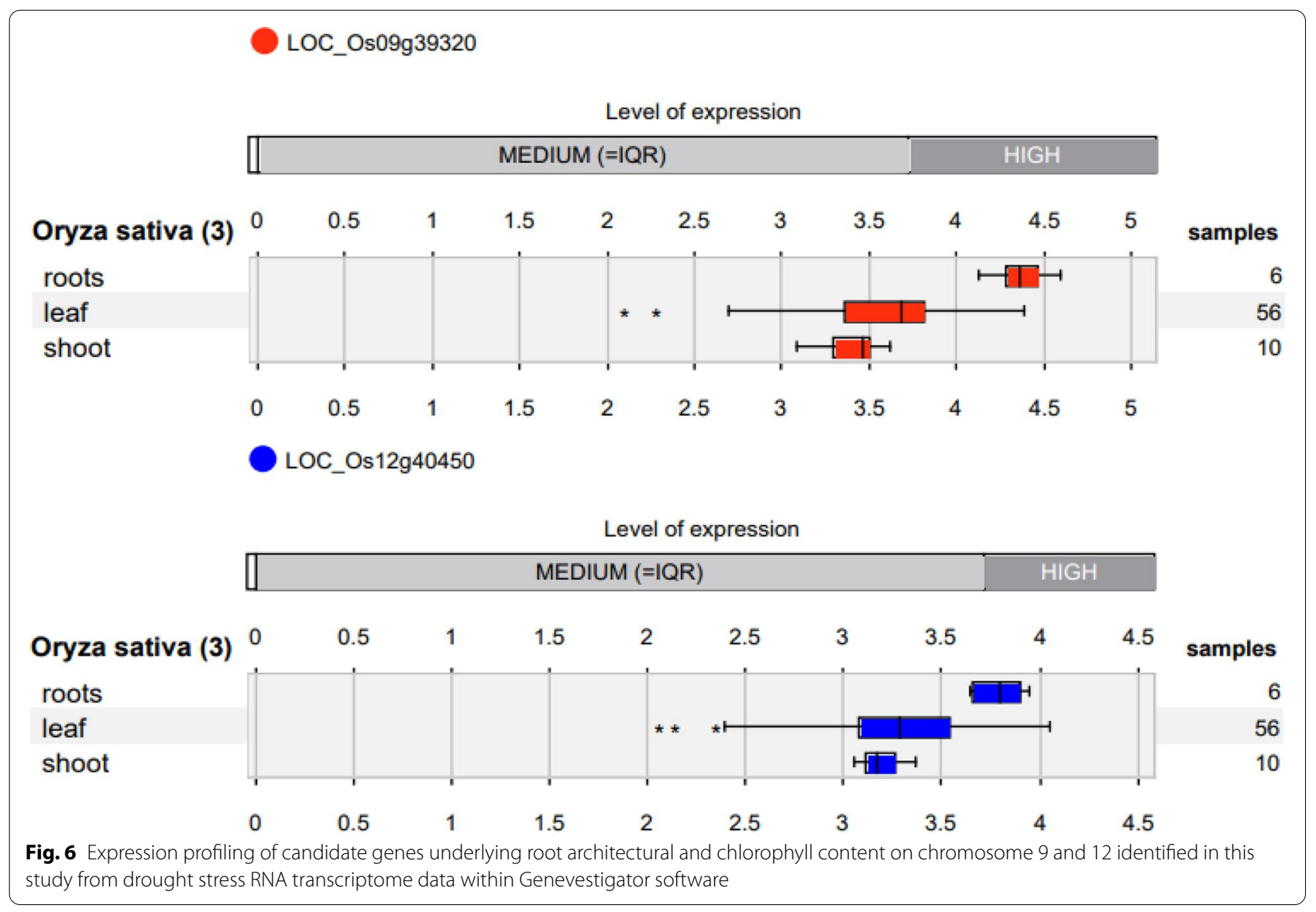


Table 8 List of haplotype variation identified in genomic regions with sequence information on selected rice landraces

\begin{tabular}{|c|c|c|c|c|c|c|}
\hline Chr. (Physical position in $\mathrm{Mb}^{\mathrm{a}}$ ) & Marker located & $\begin{array}{l}\text { Reference } \\
\text { Allele }\end{array}$ & Alt Allele & Position (Mb) & SNP type & $\begin{array}{l}\text { Traits associated in } \\
\text { MLM approach }\end{array}$ \\
\hline CHR1 (9318264-9318812) & RM1032 & $\begin{array}{l}\mathrm{T} \\
\mathrm{C}\end{array}$ & $\begin{array}{l}C \\
A\end{array}$ & $\begin{array}{l}9318278 \\
9318295\end{array}$ & $\begin{array}{l}\text { Up-stream gene variant } \\
\text { Intergenic region variant }\end{array}$ & PH, RL (Panel II) \\
\hline CHR4 (13083892-13084502) & RM5633 & $\begin{array}{l}\mathrm{T} \\
\mathrm{A} \\
\mathrm{A}\end{array}$ & $\begin{array}{l}\mathrm{C} \\
\mathrm{T} \\
\mathrm{C}\end{array}$ & $\begin{array}{l}13083944 \\
13083963 \\
13084032\end{array}$ & $\begin{array}{l}\text { Intergenic region variant } \\
\text { Intergenic region variant } \\
\text { Intergenic region variant }\end{array}$ & $\begin{array}{l}\text { DSI, RYR (Panel I) } \\
\text { SPAD, Chl, SLA (Panel II) }\end{array}$ \\
\hline CHR6 (31082906-31089743) & RM1031 & G & A & 31089179 & Down-stream gene variant & SF (Panel I) \\
\hline CHR11 (19926456-19926984) & RM5961 & $\begin{array}{l}\mathrm{T} \\
\mathrm{A}\end{array}$ & $\begin{array}{l}G \\
G\end{array}$ & $\begin{array}{l}19926506 \\
19926513\end{array}$ & $\begin{array}{l}\text { Down-stream gene variant } \\
\text { Down-stream gene variant }\end{array}$ & $\begin{array}{l}\text { 1000GW (Panel I) } \\
\text { PH, CID, SLA (Panel II) }\end{array}$ \\
\hline
\end{tabular}

Abbreviations: Ch/ Chlorophyll content, CID Carbon Isotope Discrimination, DSI Drought susceptibility index, PH Plant Height, RL Root length, RYR Relative Yield Ratio, SPAD Chlorophyll content (\%), SLA Specific Leaf Area, SF Spikelet Fertility, 1000GW Thousand grain weight

a The physical position of SSR markers and genes underlying were obtained from www.ricebase.org

found in all accessions evaluated in this study with single base pair, $\mathrm{C}$ in contrast to reference genome. Further sequence level variation was compared between two elite varieties used (PTB51 and Jaya) with nine landraces studied (Table 9). The genomic region, around RM1032 on chromosome associated with PH and RL, revealed two SNPs different in PTB8 (Thavalakannan) than elite varieties. PTB8 (Thavalakannan) and Kalladiyar accessions also recorded lower SLA were found to have three different SNPs around RM5633 region (Table 9). PTB26 also found to harbor novel allele to improve SF $(31089179 \mathrm{Mb})$ on chromosome 6 near RM1031 under water stress. Mining another genomic region on chromosome 11 associated with $1000 \mathrm{GW}$ revealed the accession PTB25 (Thonnuran) to have allele similar to elite variety, PTB51, whereas other accessions PTB26 (Chenkayama) and Gandhakasala have novel alleles than elites for use as future breeding targets.

\section{Discussion and conclusion}

Rice is a staple food for more than half of global population and South East Asia as a origin of rice with 88,681 different varieties which includes 55,615 landraces [102]. Rice land races are valuable genetic resources for improving agronomic traits, resilience and yield optimization under stress environments [60,61]. Rice cultivation in Kerala, south-western corner of the Indian peninsular region dates back to $3000 \mathrm{~B}$. C, holds valuable genetically diverse wild and cultivated rice accessions [103]. Recent efforts in rice breeding program enabled genetic improvement towards drought adaptation through conventional mapping approach [12, 14, 104, 105], marker assisted selection of high yielding varieties or by selection of secondary traits related to drought tolerance $[10,13,23,106]$. Wild crop relatives, wild/weedy species and primitive landraces are valuable genomic resources to identify new alleles for yield improvement in

Table 9 List of SNP variation identified in rice landraces for potential use as molecular markers in drought rice breeding

\begin{tabular}{|c|c|c|c|c|c|}
\hline $\begin{array}{l}\text { Trait Association } \\
\text { (Marker linked) }\end{array}$ & Chr. Phys. position (Mb) ${ }^{a}$ & Elite allele & Position (Mb) & $\begin{array}{l}\text { Landrace } \\
\text { allele }\end{array}$ & Landrace allele present in \\
\hline $\begin{array}{l}\mathrm{PH} / \mathrm{RL} \\
(\mathrm{RM} 1032)\end{array}$ & $\begin{array}{l}\text { CHR1 } \\
9318264-9318812\end{array}$ & $\begin{array}{l}\text { C } \\
\text { A }\end{array}$ & $\begin{array}{l}9318278 \\
9318295\end{array}$ & $\begin{array}{l}\mathrm{T} \\
\mathrm{C}\end{array}$ & PTB 8 \\
\hline $\begin{array}{l}\text { SPAD/ Chl/ SLA } \\
\text { (RM5633) }\end{array}$ & $\begin{array}{l}\text { CHR4 } \\
13083892-13084502\end{array}$ & $\begin{array}{l}\mathrm{C} \\
\mathrm{T} \\
\mathrm{C}\end{array}$ & $\begin{array}{l}13083944 \\
13083963 \\
13084032\end{array}$ & $\begin{array}{l}\mathrm{N} \\
\mathrm{N} \\
\mathrm{N}\end{array}$ & $\begin{array}{l}\text { All four accessions: PTB8, Kalladiyar, Gand- } \\
\text { hakashala, Jeerakashala }\end{array}$ \\
\hline \multirow[t]{2}{*}{$\begin{array}{l}\mathrm{PH} / \mathrm{CID} / \mathrm{SLA} / 1000 \mathrm{GW} \\
\text { (RM5961) }\end{array}$} & $\begin{array}{l}\text { CHR11 } \\
19926456-1926984\end{array}$ & $\mathrm{~T}$ & 19926506 & $\begin{array}{l}N \\
K \\
G\end{array}$ & $\begin{array}{l}\text { PTB51, PTB25 } \\
\text { Gandhakashala } \\
\text { PTB26 }\end{array}$ \\
\hline & & A & 19926513 & $\begin{array}{l}N \\
R \\
G\end{array}$ & $\begin{array}{l}\text { PTB51, PTB25 } \\
\text { Gandhakashala } \\
\text { PTB26 }\end{array}$ \\
\hline $\begin{array}{l}\text { SF } \\
\text { RM1031 }\end{array}$ & $\begin{array}{l}\text { CHR6 } \\
31082906-31089743\end{array}$ & $\mathrm{R}$ & 31089179 & $\begin{array}{l}A \\
G \\
R\end{array}$ & $\begin{array}{l}\text { Kalladiyar } \\
\text { PTB2, 10, } 25 \text { and 26, Gandhakashala, Jeerakashala } \\
\text { PTB8, Chomala }\end{array}$ \\
\hline
\end{tabular}

Abbreviations: ChI Chlorophyll content, CID Carbon Isotope Discrimination, PH Plant Height, RL Root length, SPAD Chlorophyll content (\%), SLA Specific Leaf Area, SF Spikelet Fertility, 1000GW Thousand grain weight

a The physical position of SSR markers and genes underlying were obtained from www.ricebase.org 
domesticated crop species [107] are yet to be explored. Recently wild soybean was found to harbor novel alleles to enhance root system architecture and seed yield in cultivated soybean genetic backgrounds [34, 108-110].

To our knowledge this is the first study on 99 diverse accessions specific to Kerala State of India, characterized with SSR markers, which are highly evolutionally neutral spanning complete rice genome. Among the classical markers, SSRs were selected based on several desirable genetic attributes like reproducibility, multi-allelic, wide distribution in both coding and non-coding regions of the genome. Moreover association analysis with rice accessions were successfully conducted with number of genotypes, less than or little over to 100 genotypes to identify genomic regions associated with different polygenic traits in rice. For example, Shomura et al. [111] mapped major loci governing grain length, grain width, grain widthlength ratio using 84 rice landraces. Thurber et al. [112] studied 105 weedy rice accessions to map shattering loci to understand the influence of evolutionary pathway on rice domestication. In addition to the difficulty involved in root phenotyping approaches, researchers were successful in identifying genes associated with various root architectural traits in rice with 93 temperate [113] and field study with 49 [114] landrace accessions, in wheat which is very complex in contrast to rice genome composition and ploidy levels by using 91 genotypes [115] and with model plant, Arabidopsis (96 accessions) grown under nitrogen [116] and potassium nitrate [117] treatments respectively.

Our study with two diverse rice panels, reveled valuable genetic resources to improve physiological processes and productivity in rainfed ecosystem. Combined phenotypic data across trials and panels revealed certain accessions as valuable genetic resources to increase shoot biomass [PTB10, PTB26], lower drought susceptibility index [PTB 25 , Bhadra], and higher grain yield and spikelet fertility [PTB1, PTB60]. Certain accessions like PTB1, 2, 10, 13, $15,29,30$ were found as genetic resources to stack different traits to improve rice plant performance and yielding ability under drought with optimized root system. GWAS analysis revealed rice genomic region to be associated with phenological, physiological and root traits measured across seasons in this study. GWA studies in rice were successful in identifying genomic regions for agronomic [118] and root traits $[47,65,119]$.

Comparing two diverse panels, uncommon genomic targets between panels, Panel I (RM1031) and Panel II (RM0132 and RM5633) were selected. Mining of publically available transcriptome datasets reveled the gene, LOC_Os06g51330 underlying RM1031 region associated with SF will be an interesting target to increase seed setting under stress. The genes underlying Panel II specific targets (RM0132 and RM5633), LOC_Os01g16414 and LOC_Os04g23040 associated with plant height, leaf physiological and root architectural traits are valuable targets to improve rice productivity under stress. Colocation of genomic regions identified in this study with previous rice QTL/association mapping studies [66-75, 120] are encouraging and are key candidate targets for introgression to develop next generation rice varieties drought tolerance. Seed yield under stress is a complex trait and a seamless benefit occurs out of coordinated activity of root and shoot physiological traits combined. Thus, identifying genomic regions that are associated with key physiological parameters and root traits are critical to optimize soil resources and improve yield under stress. The accessions, PTB2 (Ponnaryan), PTB8 (Thavalakannan), PTB10 (Thekkancheera), PTB25 (Thonnuran), PTB26 (Chenkayama), PTB30 (Chuvanna Modan), Gandhakashala, Jeerakasala and Kalladiyar are valuable genetic resources to combine different physiological, root architectural and seed yield to improve stress resilience and productivity in rainfed ecosystem. Key genomic targets identified on chromosome 1 (PH/RL), 4 (chlorophyll content/SLA), 6 (SF) and 11 (PH/CID/SLA/1000GW) and their allelic variation in the genes underlying these QTLs are novel targets for use in rice drought breeding program. The SNPs identified in these key genomic targets are valuable and have potential to be developed as KASP markers to facilitate tracking and introgression of these target traits into elite rice cultivars suited to rainfed ecosystem.

\section{Methods}

Field evaluation of diverse panel for physiological and agronomic traits (trials 1 and 2) Genetic materials

Eighty-one diverse rice accessions (Panel 1) used for drought screening and identify marker trait association are listed in Supplementary Table 1. This panel includes indigenous land races (45 accessions) and improved cultivar (36 varieties) from R.A.R.S., Pattambi, Kerala Agricultural University and National Rice Research Institute, Cuttack (ICAR-NRRI), Odisha. Most of the landraces studied had an average yield potential of $2-3 \mathrm{t} / \mathrm{ha}$, tolerant to major pests and water stress. The improved varieties were short and medium duration with red or white bold grain type with yield potential of 5-6t/ha, but with moderately tolerant or susceptible to abiotic stresses. This study protocol comply with relevant institutional, national, and international guidelines and legislation.

\section{Experimental details}

The experiment was conducted at Regional Agricultural Research Station, Pattambi, Kerala Agricultural 
University, India $\left(10^{\circ} 48^{\prime} 41.1^{\prime \prime} \mathrm{N} 76^{\circ} 11^{\prime} 24.9^{\prime \prime} \mathrm{E}\right)$, oldest rice research station in Kerala with managed irrigation facility for drought stress phenotyping studies. This experimental site is rice target environment and severely prone to heat and drought stresses. The selected diverse panel were grown in field site during wet season; Mundakan (August -December) of 2017 (Trial 1) and dry season; Puncha (January -May), 2018 (Trial 2). The experiment was laid out in alpha lattice design with two replications in both control and irrigated treatments. In both seasons, wet (Trial 1) and dry (Trial 2), $10 \mathrm{~g}$ seeds of each genotype were planted in pots filled with soil, sand and cattle manure with equal $\mathrm{v} / \mathrm{v}$ ratio. Twenty-one days old seedlings were transplanted to the open field at the rate of 2 seedlings/ hill. After 8 days of transplanting, gap filling was done and one healthy seedling was maintained per hill. Each genotype was transplanted in four rows of $2 \mathrm{~m}$ length with a spacing of $20 \times 15 \mathrm{~cm}$. Management practices were followed as per package of practices recommendation of Kerala Agricultural University. Fertilizer dose of N: P: K in the ratio of 90:45:45 Kg/ha in three split doses @ 1/3 dose of each fertilizer at basal, tillering and at panicle initiation stages. Blast incidence was controlled by using Nativo@4g/10l of water to impose water stress, irrigation was withheld for 25 consecutive days at the panicle initiation stage. Measurements on morphological and physiological parameters were recorded after 10 days of stress imposition. After stress period, re-watering was done at reproductive stage and maintained till physiological maturity. During harvest, data on plant production traits were recorded in both control and drought treatments. To quantify the soil moisture and the level of water stress data on moisture content was estimated using gravimetric method.

Physiological parameters such as leaf rolling score and drying score was done according to the Standard Evaluation System for Rice (SES) of IRRI, Philippines. Leaf rolling and drying scores were taken after 10 days of drought imposition as when leaf tissues showed drought symptoms during the time between $12 \mathrm{pm}$ and $1 \mathrm{pm}$. Leaf temperature was measured using infrared thermometer (AG-42, Teletemp Corporation, CA, USA) with an $8^{\circ}$ field of view and equipped with a 10.5- to $12.5-\mu \mathrm{m}$ band pass filter, as described [121]. The measurement was made at noon by facing south to minimize the effects of sunlight. Cell membrane stability index was estimated as per the procedure described [122]. The relative leaf water content in percentage was measured based on the method described [123]. Total chlorophyll content was estimated by the method [124] and from that chlorophyll stability index was calculated using formula. Chlorophyll stability index $(\%)=($ Total chlorophyll content at drought stress/
Total chlorophyll content at irrigated condition) X 100 . Plant production traits like yield per plant was derived weighing filled grains in each panicle expressed in grams. Thousand-grain weight was measured from seeds selected randomly from each replication and weighed. Spikelet fertility (\%) was calculated as per standard formula, Spikelet fertility $(\%)=($ Number of fertile spikelet/ Total number of spikelets) X 100. Drought susceptibility index was measured according to Fisher and Maurer [125]. Percentage relative yield reduction (RYR) under stress was computed as per following equation: $R Y R=1$ - (grain yield in drought stress / grain yield in irrigated condition) X 100.

\section{Evaluation of root architectural traits in diverse rice panel study (trials 3 and 4 )}

A previous study [25] with another diverse panel of 81 accessions (Panel II) adapted to target rainfed environments (Supplementary Table 1). This panel includes medium duration rice landraces and improved varieties with average yielding potential of $2.5 \mathrm{t} / \mathrm{ha}(45)$ and $4-5 \mathrm{t} /$ ha (36), respectively. Only 63 rice accessions are common across Panel I and II studied in different rice seasons prevalent in rice ecosystem of Kerala at the field with root phenotyping facility located. Rice seeds were planted in a specially constructed "root structure" of $5 \mathrm{ft} . \times 10 \mathrm{ft} . \times 60 \mathrm{ft} .(\mathrm{H} \times \mathrm{W} \times \mathrm{L})$ during cropping season, Virippu (June -September) in 2011and 2013. Five seeds per accessions were sowed in "root structure" which is located at $10^{\circ} 48^{\prime} 41.1^{\prime \prime} \mathrm{N} 76^{\circ} 11^{\prime} 24.9^{\prime \prime} \mathrm{E}$ within Regional Agricultural Research station (RARS), Pattambi, Kerala Agricultural University (KAU), India. Thinning was done on 18th day and retained only one plant/hill. Each genotype were planted in a row of $2 \mathrm{~m}$ length with a spacing of $20 \times 15 \mathrm{~cm}$ and replicated twice. The crop was sole depend on rainfall as source of irrigation. Fertilizer dose of N:P:K in the ratio of 90:45:45 Kg/ha in three split doses@1/3 dose of each fertilizer at basal, tillering and at panicle initiation stages. Blast incidence was controlled by using Nativo@4g/10L water. After 60 days after planting (DAP) measurements on Specific leaf area (SLA) and SPAD measurement on chlorophyll content was made as detailed [25]. Seventy days after sowing root architectural traits were measured.

Five leaves from actively growing rice seedlings were collected for CID analysis 50 days after sowing. Fully opened leaves were dried in oven at $80^{\circ} \mathrm{C}$ for 3 days and powered the leaves using ball and mill. The water use efficiencies (WUE) of 81 rice accessions studied in the study was measured using $\Delta^{13} \mathrm{C}$ values, negatively associated with WUE. An isotope ratio mass spectrometer (IRMS) interfaced with a suitable combustion system is used for the determination of $\Delta \Delta^{13} \mathrm{C}$. The plants ability to 
discriminate against the heavy isotope of carbon $\left({ }^{13} \mathrm{C}\right)$, resulting in the depletion of $13 \mathrm{C}$ content in biomass compared with atmospheric air during photosynthesis activity was used to measure CID [126]. $\Delta^{13} \mathrm{C}$ was measured as the ratio of the partial pressures of $\mathrm{CO}_{2}$ inside the leaf to that in ambient air $(\mathrm{Pi} / \mathrm{Pa})$, as follows: $\Delta^{13} \mathrm{C}=\mathrm{a}+(\mathrm{b}-\mathrm{a})$ $\mathrm{Pi} / \mathrm{Pa}$; where, $\mathrm{a}$ and $\mathrm{b}$ are isotope fractionations that occur during diffusion through stomata and carboxylation by Rubisco respectively.

SPAD (SPAD 502 plus chlorophyll meter, Spectrum Technologies, Inc.) was used to measure the chlorophyll content based on light absorbance and/or transmittance characteristics at $430 \mathrm{~nm}$ and $750 \mathrm{~nm}$ on a leaf tissue. Percent chlorophyll content was measured between 10.00 and $16.00 \mathrm{~h}$ on second or third fully expanded leaf lamina avoiding the mid-rib portion. Actual chlorophyll content was measured using lab based assay [124]. The specific leaf area (SLA) is measured as the ratio of leaf area to leaf dry weight, an indirect measure of leaf expansion as described [25]. Higher SLA phenotypic values represents larger leaf surface area available for transpiration, inversely related to WUE. Data on SLA was measured on completely expanded second or third leaf from main stem apex using a leaf area meter (CI-203, CID Bioscience, UK). Dry weight on the leaf used to measure SLA was collected after dried in a hot-air oven at $70^{\circ} \mathrm{C}$ for 3 days and weighed. SLA was calculated as using the formula as below: SLA $(\mathrm{cm}-2 \mathrm{~g}-1)=($ leaf area $/$ leaf dry weight).

After 70 days of planting data on plant height and biomass were collected. Then the brick wall in the root phenotyping structure was dismantled and strong jet of water was used to remove the excess soil adhering plant root system. The soil particles adhering close to rice roots were removed carefully and data on root length, root volume, root dry weight were measured as described [25]. Root length was manually measured using a ruler from shoot tiller-root junction to the deepest root. Root volume was measured in cubic centimeter by water displacement method, by immersing cleaned soil free roots into a measuring cylinder with 11 of water. Root dry weight was obtained from oven dried roots at $80^{\circ} \mathrm{C}$ for $48 \mathrm{~h}$.

\section{Effect of reproductive stress on rice agronomic traits (trial 5)}

A subset of 35 diverse lines (Supplementary Table 1) within 81 diverse panels was evaluated under drought stress imposed on reproductive stage stress following a Completely Randomized Design in a rainout shelter of Department of Plant Physiology, College of Agriculture, Kerala Agricultural University during the year 2017. The subset genotypes were raised in polythene tubes of
$25 \mathrm{~cm}$ diameter and $1 \mathrm{~m}$ height. Plants in both control and drought treatments were irrigated regularly until panicle initiation (PI) stage. After PI, irrigation was withheld for a period of 15 days in drought treatment PVCs to evaluate leaf, root and yield responses under reproductive stage water limitation. The control plants are irrigated regularly till maturity. The methodology used to quantify leaf-rolling response and root traits are published earlier [26].

\section{Molecular marker genotyping}

Leaf tissues of 20 days old plants on 81 diverse rice panel were collected in a small Ziploc bags in an ice cooler to extract genomic DNA. The leaf samples were stored at $-80^{\circ} \mathrm{C}$ until processed. Genomic DNA was extracted using the method by Dellaporta et al. [127] and the quality of resultant DNA was determined using spectrophotometer (ELICO, SL $21 \mathrm{UV}$-Vis spectrophotometer) based on absorbance ratio of $260 \mathrm{~nm}$ to $280 \mathrm{~nm}$ (A 260/A 280) between 1.7 and 1.8 [128]. DNA quality was also assessed using gel electrophoresis with $5 \mu \mathrm{l}$ of crude DNA sample on agarose gel $(0.8 \%)$ stained with ethidium bromide. A total of 100 SSR markers spanning whole rice genome across 12 chromosomes were selected from published rice literatures on drought tolerance (Supplementary Table 7). The genotyping was performed at College of Agricultural Vellayani, Thiruvannathapuram, Kerala Agricultural University (KAU), India.

Gradient cycle was performed in Master Cycler gradient 5331 (Eppendorf version 2.30.31-09, Germany) to optimize the annealing temperature suitable for SSR genotyping in rice diverse panel. A final sample volume of $20 \mu \mathrm{l}$ was used for PCR reaction with reaction mixture contained $30 \mathrm{ng} / \mu \mathrm{l}$ DNA, $2.5 \mathrm{mM}$ dNTPs, $30 \mathrm{ng}$ forward and reverse primer each, 1 unit of Taq DNA polymerase with $10 \mathrm{X}$ reaction buffer and $25 \mathrm{mM}$ $\mathrm{MgCl}_{2}$. Genotyping was performed using the following PCR cycle: $94^{\circ} \mathrm{C}$ for $5 \mathrm{~min}(1 \mathrm{x}), 35$ cycles each of $94^{\circ} \mathrm{C}$ for $30 \mathrm{~s}, 50-60^{\circ} \mathrm{C}$ (vary depend on SSR annealing temperature) for $30 \mathrm{~s}, 72^{\circ} \mathrm{C}$ for $1 \mathrm{~min}$ with final cycle at $72^{\circ} \mathrm{C}$ for $5 \mathrm{~min}$ and $4{ }^{\circ} \mathrm{C}$ for infinity. After PCR amplification, $3 \mu \mathrm{L}$ of gel loading dye (Bromophenol blue) was added directly to the reaction tubes and spun for few seconds in a micro centrifuge. The PCR amplicons were resolved on $2 \%$ agarose gel stained with ethidium bromide along with marker (100 bp ladder). Electrophoresis (Bio-Rad, Deutsch) was performed using $1 \mathrm{X}$ TBE as buffer solution at $80 \mathrm{~V}$ with running time of $90 \mathrm{~min}$. The gel was visualized under UV $(312 \mathrm{~nm})$ transilluminator in gel documentation system (Syngene G-box documentation system) and scored as 1 for presence or 0 for absence of specific allele. 


\section{Association mapping analysis}

Population structure of 81 rice genotypes was estimated using a STRUCTURE software V2.3.4 based on Bayesian clustering algorithm [128]. Five independent runs were made to detect the optimum number of subpopulations, with $K$ values ( $K=2$ to 8$)$ using burn and run lengths of 50,000 . The results were imported to STRUCTUREHARVESTER software to calculate exact value of $1 \mathrm{~K}$ [129]. TASSEL v.5 software package was used to calculate Linkage Disequilibrium (LD) for 81 diverse rice accessions at $p$-value $<0.05$. The analysis was conducted by considering genotypes with and without admixture identified by software STRUCTURE at $K=2$. The LD was estimated by considering the squared correlation coefficient $\left(\mathrm{r}^{2}\right)$ between SSR markers and plotted as triangle plots to evaluate LD blocks in association genetic analysis. The marker-trait association was calculated using TASSEL 5 based on General Linear Model (GLM) based on Q-matrix based on the population structure and a Mixed Linear Model based on Q-matrix and the kinship-matrix (MLM) [130]. In both models the markers with $p$-value $<0.05$ and $r^{2}$ value $>0.1$ were considered as significant markers for further analysis. To identify genes underlying major QTLs flanked by SSR markers, two-hundred Kb (both up and downstream) around the SSR marker physical positions were mined using Ricebas e[131] and QTL co-location across published literature were obtained from Rice SNP-Seek Database [132]. In general, the average range of LD decay in different rice sub-populations ranged from 100 to $500 \mathrm{~kb}$ [133], thus two-hundred $\mathrm{Kb}$ (both up and downstream) around the SSR marker physical position were mined to identify possible causal loci underlying trait of interest. Similar approach of using SSR physical position to find causal loci were proven for various agronomic traits governed by polygenes like grain number [133] and drought tolerance [106], yield under drought [134] and nitrogen starvation [135]. The tissue specific expression pattern of genes underlying QTLs were mined within rice Affymetrix and global transcriptome data integrated into Genevestigator software [136].

\section{Genotyping by sequencing (GBS) of land races and elite varieties}

GBS data on eleven accessions including 9 landraces (Supplementary Table 8) ([Chenkazhama; PTB26, Cholmala, Gandhakasala, Jeerakasala, Kalladiyar, Ponnaryan; PTB2, Thavalakannan; PTB8, Thekkan Cheera; PTB10 and Thonnuran]) and two elite varieties [PTB51 (Athira) and Jaya] were used for further analysis [101]. These eleven accessions represent wide variety of rice taxa [137] [PTB51 (Athira), PTB26 (Chenkayama), Chomala, Gandhakasala, Jaya, Jeerakasala, Kalladiyar, PTB2 (Ponnaryan), PTB8 (Thavalakannan), PTB10
(Thekkancheera) and PTB25 (Thonnuran)]. Accessions representing Oryza meyeriana subsp. Granulate from Wynad district: Chomala, Gandhakasala and PTB25 (Thonnuran) and PTB8 (Thavalakannan) from Kasaragod representing O. sativa f. spontanea (weedy rice) represents novel alleles that would improve grain yield and stress resilience in elite rice cultivars [137]. Each accession library was prepared after restriction digestion of $10-20 \mu \mathrm{g}$ of genomic DNA by ApeK1+Pst1 enzyme followed by ligation of barcoded adapters. Library quality check was performed using Agilent Tape Station and sequenced on Illumina Nextseq 500 platform with $2 \times 150 \mathrm{bp}$ v2 chemistry. Further details on read depth and SNP calling can be obtained from previously published literature [101].

\section{Identification of conserved SNP haplotypes among rice landraces}

Whole-genome scans were performed by comparing GBS data between 2 elite rice lines and 9 landraces at nucleotide level to identify alleles similar across rice landraces but different than elite varieties. Each candidate gene underlying marker-trait association were analyzed to identify conserved genic single nucleotide polymophic (SNP) variation among rice landraces for potential use as marker to introgress drought tolerance in future rice breeding program. Similar approach for comparing deep sequence data on elite and landraces/ wild accessions revealed a SNP allele with higher frequency among upland rice variety to regulate lateral root density [138].

\section{Study protocol comply with relevant institutional, national, and international guidelines and legislation \\ Statistical analysis}

The phenotyping data were analyzed statistically using the SAS program (SAS institute Inc., 1990). Principal component analysis, principal co-ordinate analysis and cluster analysis were done using $\mathrm{R}$ environment of statistical computing ( $\mathrm{R}$ core Team, 2013). Predictors for leaf rolling and grain yield under stress were identified using bootstrap forest model integrated into JMP SAS software (v.15.1.0).

\section{Permission to collect samples}

Memorandum of Understanding between institutions are needed to collect the samples from Regional Agricultural Research Station, Pattambi, Kerala, India.

Abbreviations

GBS: Genotyping By Sequencing; WUE: Water Use Efficiency; QTL: Quantitative Trait Loci; GWAS: Genome Wide Association Study; DSI: Drought 
Susceptibility Index; CID: Carbon Isotope Discrimination; SLA: Specific Leaf Area; PCA: Principal Component Analysis; PC: Principal Component; PH: Plant Height; DFF: Days to 50\% flowering; SB: Shoot Biomass; RB: Root Biomass; RL: Root Length; RV: Root Volume; SDW: Shoot Dry Weight; RDW: Root Dry Weight; SPAD: Soil Plant Analysis Department; RWC: Relative Water Content; CMS: Cell Membrane Stability; CSI: Chlorophyll Stability Index; SF: Spikelet Fertility; LT: Leaf Temperature; LR: Leaf Rolling; RYR: Relative Yield Reduction; LD: Leaf Drying; SSR: Simple Sequence Repeat; GLM: General Linear Model; MLM: Mixed Linear Model; DNA: Deoxyribo Nucleic Acid; RNA: Ribo Nucleic Acid; PCR: Polymerase Chain Reaction; PI: Panicle Initiation.

\section{Supplementary Information}

The online version contains supplementary material available at https://doi. org/10.1186/s12870-021-03272-3.

\section{Additional file 1: Supplementary Table 1. List of rice diverse panels} (Panel I and II) evaluated in the study.

Additional file 2: Supplementary Table 2. Correlation of phenological, physiological traits with yield under water stress in trial 1.

Additional file 3: Supplementary Table 3. Correlation of phenological, physiological traits with yield under water stress in trial 2.

Additional file 4: Supplementary Table 4. Correlation among morphophysiological and root traits measured under rainfed condition in trial 3.

Additional file 5: Supplementary Table 5. Marker-trait association identified with GLM analysis in diverse panel I phenotypic data measured under water stress.

Additional file 6: Supplementary Table 6. Marker-trait association identified with GLM analysis in diverse panel II phenotypic data measured under water stress.

Additional file 7: Supplementary Table 7. List of SSR markers used in genotyping diverse rice panels (Panel I and II).

Additional file 8: Supplementary Figure 1. Variation in precipitation and relative humidity experienced by diverse rice panels evaluated in field trials 1-4. Trial 1(2017), Trial 2(2018), Trial 3(2011) and Trial 4 (2013).

Additional file 9: Supplementary Table 8. SNP variation identified in 11 rice land race accessions used in this study.

\section{Acknowledgements}

Authors acknowledge the grants from Kerala State Council for Science, Technology and Environment, Government of Kerala, India.

\section{Authors' contributions}

BR and SK conceptualized the study. NN, BR, SK, SRP, SJ, MV assisted in data curation. AM generated GBS data. NN, SRP, SK, SJ, MV, JMPK, RR assisted in data analysis. BR, SK, MV, SRP, APS, RS, VMM, JVG provided the resources for research study. BR, APS, RS, VMM, JVG, KHMS supervised the study and data collection. All authors reviewed and approved the manuscript. The datasets generated during and/or analysed during the current study are available from the corresponding authors on reasonable request.

\section{Funding}

The work was supported by Young Investigator's Programme in Biotechnology, Kerala State Council for Science, Technology and Environment, Government of Kerala and Ph.D. grant from Kerala Agricultural University.

\section{Availability of data and materials}

Genotyping By Sequencing data with SNP information is available as Additional file 4. This SNP data can be shared on the request and mutual consent. Seeds of germplasm material are available from Regional Agricultural Research Station, Pattambi, Kerala Agricultural University, India. Please contact Dr. Manickavelu Alugu (amanicks@cukerala.ac.in) for the SNP data and Dr. Beena (beena.r@kau.in) for germplasm request.

\section{Declarations}

Ethics approval and consent to participate

Not applicable.

\section{Consent for publication}

Not applicable.

\section{Competing interests}

All authors declare that the research was conducted in the absence of any commercial or financial relationships that could be construed as a potential conflict of interest.

\section{Author details}

${ }^{1}$ Department of Plant Physiology, College of Agriculture, Vellayani, Kerala Agricultural University, Thiruvananthapuram, Kerala, India. ${ }^{2}$ BASF, Morrisville, NC 27560, USA. ${ }^{3}$ Department of Genomic Science, Central University of Kerala, Kasaragod, Kerala, India. ${ }^{4}$ Indian Council of Agricultural Research (ICAR)-Central Rice Research Institute, currently named National Rice Research Institute (NRRI), Cuttack, Odisha, India. ${ }^{5}$ Regional Agricultural Research Station, Pattambi, Kerala Agricultural University, Palakkad, Kerala, India. ${ }^{6}$ Indian Council of Agricultural Research (ICAR)-Central Tuber Crops Research Institute, Sreekaryam, Thiruvananthapuram, Kerala, India. ${ }^{7}$ Chaudhary Charan Singh (CCS) Haryana Agricultural University, Hissar, India. ${ }^{8}$ Department of Plant Breeding and Genetics, College of Agriculture, Vellayani, Kerala Agricultural University, Thiruvananthapuram, Kerala, India. ${ }^{9}$ The UWA Institute of Agriculture, The University of Western Australia, Perth, WA, Australia.

Received: 18 June 2021 Accepted: 29 September 2021

Published online: 23 October 2021

\section{References}

1. FAO Rice Market Monitor and Agricultural Organization of the United Nations. Rice Market Monitor. 2017;.XX(1):1-27, Rome, Itali.

2. Uga Y, Sugimoto K, Ogawa S, Rane J, Ishitani M, Hara N, et al. Control of root system architecture by DEEPER ROOTING 1 increases rice yield under drought conditions. Nat Genet. 2013;45:1097-102.

3. Mohanty N, Sekhar MR, Reddy DM, Sudhakar P. Genetic variability and character association of agro-morphological and quality characters in rice. ORYZA-An Int J Rice. 2012;49:88-92.

4. Bouman B. A conceptual framework for the improvement of crop water productivity at different spatial scales. Agric Syst. 2007;93:43-60.

5. Pathak H, Nayak AK, Jena M, Singh ON, Samal P, Sharma SG. Rice research for enhancing productivity, profitability and climate resilience. Cuttack: ICAR-National Rice Research Institute; 2018. p. 527.

6. Pandey S, Bhandari H, Ding S, Prapertchob P, Sharan R, Naik D, et al. Coping with drought in rice farming in Asia: insights from a crosscountry comparative study. Agric Econ. 2007:37:213-24.

7. Venuprasad R, Dalid CO, Valle MD, Zhao D, Espiritu M, Sta Cruz MT, et al. Identification and characterization of large-effect quantitative trait loci for grain yield under lowland drought stress in rice using bulk-segregant analysis. Theor Appl Genet. 2009;120:177-90.

8. Luo LJ. Breeding for water-saving and drought-resistance rice (WDR) in China. J Exp Bot. 2010;61:3509-17. https://doi.org/10.1093/jxb/erq185.

9. Amudha K, Thiyagarajan K, Robin S, Prince SJK, Poornima R, Suji KK. Heterosis under aerobic condition in hybrid rice. Electron J Plant Breeding. 2010;1:769-75.

10. Kanagaraj P, Prince S, Annie SJ, Biji KR, Paul SB, Senthil A, et al. Microsatellite markers linked to drought resistance in rice (Oryza sativa L.). Curr Sci. 2010;98:836-9.

11. Mutava RN, Prince SJK, Syed NH, Song L, Valliyodan B, Chen W, et al. Understanding abiotic stress tolerance mechanisms in soybean: a comparative evaluation of soybean response to drought and flooding stress. Plant Physiol Biochem. 2015;86:109-20.

12. Prince SJ, Beena R, Gomez SM, Senthivel S, Babu RC. Mapping consistent rice (Oryza sativa L.) yield QTLs under drought stress in target rainfed environments. Rice. 2015;8:25. 
13. Salunkhe AS, Poornima R, Prince SJK, Kanagaraj P, Annie SJ, Amudha K, et al. Fine mapping QTL for drought resistance traits in rice (Oryza sativa L.) using bulk segregant analysis. Mol Biotechnol. 2011;49:90-5.

14. Suji KK, Biji KR, Poornima R, Prince SJK, Amudha K, Kavitha S, et al. 2012a. Mapping QTLs for plant phenology and production traits using indica rice (Oryza sativa L.) lines adapted to rainfed environment. Mol Biotechnol. 2012;52:151-60.

15. Babu RC, Nguyen BD, Chamarerk V, Shanmugasundaram P, Chezhian $\mathrm{P}$, Jeyaprakash $\mathrm{P}$, et al. Genetic analysis of drought resistance in rice by molecular markers: association between secondary traits and field performance. Crop Sci. 2003;43:1457-69.

16. Vijaylakshmi D, Beena R, Vijaylakshmi C. Heterosis for biochemical constituents and protein profiles of elite rice hybrids of Tamil Nadu. Biohelicon:Plant Physiol. 2013;1(2a):1-5.

17. Beena R, Thandapani V, Chandrababu R. Physio-morphological and biochemical characterization of selected recombinant inbred lines of rice for drought resistance. Indian J Plant Physiol. 2012a;17(2):189-93.

18. Prince SJ, Mutava RN, Pegoraro C, Oliveira ACD, Nguyen HT. Root characters. In: Kole C, editor. Genomics and breeding for climate resilient crops. Berlin: Springer; 2013. p. 67-131.

19. Cairns J, Audebert A, Mullins CE, Price AH. Mapping quantitative trait loci associated with root growth in upland rice (Oryza sativa L.) exposed to soil water-deficit in fields with contrasting soil properties. Field Crop Res. 2009;114:108-18.

20. Gowda VR, Henry A, Yamauchi A, Shashidhar H, Serraj R. Root biology and genetic improvement for drought avoidance in rice. Field Crop Res. 2011;122:1-13.

21. Kato Y, Okami M. Root morphology, hydraulic conductivity and plant water relations of high-yielding rice grown under aerobic conditions. Ann Bot. 2011;108:575-83.

22. Prince SJ, Murphy M, Mutava R, Zhang Z, Nguyen N, Kim YH, et al. Evaluation of high yielding soybean germplasm under water limitation. J Integr Plant Biol. 2016;58:475-49.

23. Suji KK, Prince SJK, Mankhar PS, Kanagaraj P, Poornima R, Amutha K, et al. Evaluation of rice (Oryza sativa L.) near iso-genic lines with root QTLs for plant production and root traits in rainfed target populations of environment. Field Crop Res. 2012;137:89-96.

24. Beena R, Praveenkumar V, Vighneswaran V, Narayankutty M. Bulked line analysis: a useful tool to identify microsatellite markers linked to drought tolerance in rice. Indian J Plant Physiol. 2018;23:7-15.

25. Beena R, Praveenkumar V, Vighneswaran V, Sindhumol P, Narayankutty $M$. Phenotyping for root traits and carbon isotope discrimination in rice genotypes of Kerala. ORYZA-An Int J Rice. 2017;54:282-9.

26. Rejeth R, Manikanta CLN, Beena R, Roy S, Manju RV, Viji MM. Water stress mediated root trait dynamics and identification of microsatellite markers associated with root traits in rice (Oryza sativa L.). Physiol Mol Biol Plants. 2020;26:1225-36

27. Prince SJ, Murphy M, Mutava RN, Durnell LA, Valliyodan B, Shannon JG, et al. Root xylem plasticity to improve water use and yield in waterstressed soybean. J Exp Bot. 2017;68:2027-36.

28. Manikanta CLN, Beena R, Roy S, Manju RV, Viji MM, Swapna A. Physiomorphological plasticity of rice (Oryza sativa L.) genotypes exposed to water stress. J Trop Agric. 2020;58(1):139-45.

29. Naresh BP, Abida PS, Beena R, Valsala PA, Nazeem PA. Morphophysiological and proteomic analysis to identify and characterise the traditional rice genotypes for drought tolerance. Indian J Plant Physiol. 2018;23(4):785-95.

30. Prince SJ, Valliyodan B, Ye H, Yang M, Tai S, Hu W, et al. Understanding genetic control of root system architecture in soybean: insights into the genetic basis of lateral root number. Plant, Cell Environ. 2019;42:212-29.

31. Courtois B, Ahmadi N, Khowaja F, Price AH, Rami JF, Frouin J, et al. Rice root genetic architecture: meta-analysis from a drought QTL database. Rice. 2009;2:115-28.

32. Soriano JM, Alvaro F. Discovering consensus genomic regions in wheat for root-related traits by QTL meta-analysis. Sci Rep. 2019;9:10537.

33. Manavalan LP, Prince SJ, Musket TA, Chaky J, Deshmukh R, Vuong TD, et al. Identification of novel QTL governing root architectural traits in an interspecific soybean population. PLoS One. 2015;10:e0120490.

34. Prince SJ, Song L, Qiu D, Santos JVM, Chai C, Joshi T, et al. Genetic variants in root architecture-related genes in a Glycine soja accession, a potential resource to improve cultivated soybean. BMC Genomics. 2015; 16:132.

35. Prince S, Hernandez T, Tayeh N, Anower R, Samac DA, Blancaflor E, Motes C, Monteros MJ. Genomic and phenomic approaches to understand root growth and development for alfalfa improvement. Plant and Animal Genome Conference Proceedings. Plant Science Research, St. Paul, Minnesota, January 13-18, 2018, San Diego, California.

36. Monteros MJ, Silvas P, Anower MR, Nadium TN. Understanding differences in alfalfa root system and their importance for abiotic stress tolerance. In: Symposium-root physiology: integration of molecular biology to functional traits. ASA, CSSA, SSSA international symposium, USA; 2017. https://scisoc.confex.com/scisoc/2017am/meeti ngapp.cgi/Paper/106166.

37. Ehdaie B, Hall A, Farquhar G, Nguyen H, Waines J. Water-use efficiency and carbon isotope discrimination in wheat. Crop Sci. 1991;31:1282-8.

38. Zhao B, Kondo M, Maeda M, Ozaki Y, Zhang J. Water-use efficiency and carbon isotope discrimination in two cultivars of upland rice during different developmental stages under three water regimes. Plant Soil. 2004;261:61-75

39. Sheshshayee MS, Parsi SG, Madhura JN, Beena R, Prasad TG, Udayakumar M. Drought phenotyping in crops: from theory to practice. In: Monneveux P, Ribaut J-M, editors. CGIAR Generation Challenge Programme/ CIMMYT; 2011.

40. Wassmann R, Jagadish SVK, Heuer S, Ismail A, Redona E, Serraj R, et al. Climate change affecting rice production: the physiological and agronomic basis for possible adaptation strategies. Adv Agron. 2009;101:59-122.

41. Beena R, Sheshshayee MS, Madhura JN, Prasad TG, Udayakumar M. Development of SSR markers and genetic variability in physiological traits in bambara groundnut (Vigna subterranea L. Verdc). In: Sabu, A and Anu A, editors. Prospects in Bioscience: Addressing the Issues. India: Springer Nature Publishing; 2012. p. 229-42.

42. Kumar A, Dixit S, Ram T, Yadaw RB, Mishra KK, Mandal NP. Breeding highyielding drought-tolerant rice: genetic variations and conventional and molecular approaches. J Exp Bot. 2014;65:6265-78.

43. Borevitz JO, Nordborg M. The impact of genomics on the study of natural variation in Arabidopsis. Plant Physiol. 2003;132:718-25.

44. Korte A, Farlow A. The advantages and limitations of trait analysis with GWAS: a review. Plant Methods. 2013;9:1-9.

45. Swamy BPM, Shamsudin NAA, Rahman SNA, Mauleon R, Ratnam W, Sta. Cruz MT, et al. Association mapping of yield and yield-related traits under reproductive stage drought stress in rice (Oryza sativa L.). Rice. 2017; 10:21

46. Beena, R. Studies on physio- morphological traits and genetic markers associated with drought responses in rice (Oryza sativa L.). Ph.D. thesis submitted to Tamil Nadu Agricultural University, Coimbatore, Tamil Nadu, India (2005).

47. Courtois B, Audebert A, Dardou A, Roques S, Ghneim-Herrera T, Droc G, et al. Genome-wide association mapping of root traits in a japonica rice panel. PLoS One. 2013;8:e78037.

48. Famoso AN, Zhao K, Clark RT, Tung CW, Wright MH, Bustamante C, et al. Genetic architecture of aluminum tolerance in rice (Oryza sativa) determined through genome-wide association analysis and QTL mapping. PLoS Genet. 2011;7:e1002221.

49. Huang X, Zhao Y, Wei X, Li C, Wang A, Zhao Q, et al. Genome-wide association study of flowering time and grain yield traits in a worldwide collection of rice germplasm. Nat Genet. 2012;44:32-9.

50. Deshmukh V, Mankar SP, Muthukumar C, Divahar P, Bharathi A, Thomas $\mathrm{HB}$, et al. Genome-wide consistent molecular markers associated with phenology, plant production and root traits in diverse rice (Oryza sativa L.) accessions under drought in rainfed target populations of the environment. Curr Sci. 2018;114:329.

51. Raju BR, Mohankumar MV, Sumanth KK, Rajanna MP, Udayakumar M, Prasad TG, et al. Discovery of QTLs for water mining and water use efficiency traits in rice under water-limited condition through association mapping. Mol Breed. 2016;36:35.

52. Verma H, Borah JL, Sarma RN. Variability assessment for root and drought tolerance traits and genetic diversity analysis of rice germplasm using SSR markers. Sci Rep. 2019;9:16513.

53. Muthukumar C, Subathra T, Aiswarya J, Gayathri V, Babu RC. Comparative genome-wide association studies for plant production traits under 
drought in diverse rice (Oryza sativa L.) lines using SNP and SSR markers. Curr Sci. 2015;109:139-47.

54. Bhattarai U, Subudhi PK. Genetic diversity, population structure, and marker-trait association for drought tolerance in US rice germplasm. Plants. 2019;8:530.

55. Pradhan SK, Pandit E, Pawar S, Naveenkumar R, Barik SR, Mohanty SP, et al. Linkage disequilibrium mapping for grain Fe and $\mathrm{Zn}$ enhancing QTLs useful for nutrient dense rice breeding. BMC Plant Biol. 2020;20:57. https://doi.org/10.1186/s12870-020-2262-4.

56. Meijón M, Satbhai SB, Tsuchimatsu T, Busch W. Genome-wide association study using cellular traits identifies a new regulator of root development in Arabidopsis. Nat Genet. 2014;46:77.

57. Huang X, Kurata N, Wei X, Wang ZX, Wang A, Zhao Q, et al. A map of rice genome variation reveals the origin of cultivated rice. Nature. 2012;490:497-501.

58. Li LF, Li YL, Jia Y, Caicedo AL, Olsen KM. Signatures of adaptation in the weedy rice genome. Nat Genet. 2017;49:811-4.

59. Wang H, Vieira FG, Crawford JE, Chu C, Nielsen R. Asian wild rice is a hybrid swarm with extensive gene flow and feralization from domesticated rice. Genome Res. 2017;27:1029-38.

60. Brozynska M, Furtado A, Henry RJ. Genomics of crop wild relatives: expanding the gene pool for crop improvement. Plant Biotechnol J. 2016;14:1070-85.

61. Mammadov J, Buyyarapu R, Guttikonda SK, Kelly Parliament K, Abdurakhmonov IY, Siva P, et al. Wild relatives of maize, rice, cotton, and soybean: treasure troves for tolerance to biotic and abiotic stresses. Front Plant Sci. 2018;9:886

62. Beena, R., An overview on QTLs linked to physio-morphological traits under water limited condition in rice (Oryza sativa L.). In: Hemantaranjan A. editor, Advances in plant physiology, an international treatise series. India, Scientific Publishers. 2012b;13:233-49.

63. Santhanalakshmi S, Shukla K, Silvas JKP. Evaluation of resistance of wild rices, Oryza spp., to the whitebacked planthopper, Sogatella furcifera (Horvath)(Homoptera: Delphacidae). Arch Phytopathol Plant Protect. 2010;43:1088-97.

64. Wang W, Mauleon R, Hu Z, Chebotarov D, Tai S, Wu Z, et al. Genomic variation in 3,010 diverse accessions of Asian cultivated rice. Nature. 2018:557:43-9.

65. Li X, Guo Z, Lv Y, Cen X, Ding X, Wu H, et al. Genetic control of the root system in rice under normal and drought stress conditions by genomewide association study. PLoS Genet. 2017;13:e1006889.

66. Huang $X$, et al. Genome-wide association studies of 14 agronomic traits in rice landraces. Nat Genet. 2010;42:961.

67. Koyama ML, Levesley A, Koebner RMD, Flowers TJ, Yeo AR. Quantitative trait loci for component physiological traits determining salt tolerance in rice. Plant Physiol. 2001;125:406-22.

68. Li Z, et al. QTL mapping of root traits in a doubled haploid population from a cross between upland and lowland japonica rice in three environments. Theor Appl Genet. 2005;1 10:1244-52.

69. Luo LJ, Li ZK, Mei HW, Shu QY, Tabien R, Zhong DB, et al. Overdominant epistatic loci are the primary genetic basis of inbreeding depression and heterosis in rice. II Grain Yield Components Genet. 2001:158:1755-71.

70. Cho YG, Kang HJ, Lee JS, Lee YT, Lim SJ, Gauch H, et al. Identification of quantitative trait loci in rice for yield, yield components, and agronomic traits across years and locations. Crop Sci. 2007;47:2403-17.

71. Zenbo T, Lishuang S, Haochi K, Chaofu L, Ying C, Kaida Z, et al. Identification of QTLs for lengthes of the top internodes and other traits in rice and analysis of their genetic effects. Yi Chuan Xue Bao Acta Genetica Sinica. 1996;23:439-46.

72. Yoshimura A, Takano-Kai N, Anno C. Linkage mapping of genes for short panicle and awn in rice. Rice Genetics Newslett. 2004;21:17-9.

73. Xu J, Zhong D, Yu S, Luo L, Li Z. QTLs affecting leaf rolling and folding in rice. Rice Genetics Newslett. 1999;16:5-53.

74. Hou MY, Wang CM, Jiang L, Wan JM, Yasui H, Yoshimura A. Inheritance and QTL mapping of low temperature germinability in rice (Oryza sativa L.). Acta Genet Sin. 2004;31:701-6.

75. Bhandari A, Sandhu N, Bartholome J, Hamadoun TVC, Ahmadi N, Kumari N, et al. Genome-wide association study for yield and yield related traits under reproductive stage drought in a diverse indica-aus rice panel. Rice. 2020;13:53.
76. Zhou LJ, Xiao LT, Xue HW. Dynamic cytology and transcriptional regulation of rice Lamina joint development. Plant Physiol. 2017;174:1728-46.

77. Lee S, Jeong H, Lee S, Lee J, Kim SJ, Park JW, et al. Molecular bases for differential aging programs between flag and second leaves during grain-filling in rice. Sci Rep. 2017;7:8792.

78. Russell SD, Gou X, Wong CE, Wang X, Yuan T, Wei X. Genomic profiling of rice sperm cell transcripts reveals conserved and distinct elements in the flowering plant male germ lineage. New Phytol. 2012;195:560-73.

79. Sun W, Xu XH, Lu X, Xie L, Bai B, Zheng C, et al. The rice phytochrome genes, PHYA and PHYB, have synergistic effects on anther development and pollen viability. Sci Rep. 2017;7:6439.

80. Norton GJ, Aitkenhead MJ, Khowaja FS, Whalley WR, Price AH. A bioinformatic and transcriptomic approach to identifying positional candidate genes without fine mapping: an example using rice rootgrowth QTLs. Genomics. 2008;92:344-52.

81. Huang L, Schiefelbein J. Conserved gene expression programs in developing roots from diverse plants. Plant Cell. 2015;27:2119-32.

82. Wu Y, Kikuchi S, Yan H, Zhang W, Rosenbaum H, Iniguez AL, et al. Euchromatic subdomains in rice centromeres are associated with genes and transcription. Plant Cell. 2011;23(11):4054-64.

83. Nakano Y, Nishikubo N, Sato-Izawa K, Mase K, Kitano H, Kajita S, et al. Transcription profiling identifies candidate genes for secondary cell wall formation and hydroxycinnamoyl-arabinoxylan biosynthesis in the rice internode. Plant Biotechnol. 2013;30:433-46.

84. Kudo T, Akiyama K, Kojima M, Makita N, Sakurai T, Sakakibara H. UniVIO: a multiple omics database with hormonome and transcriptome data from rice. Plant Cell Physiol. 2013;54:e9.

85. Liu H, Yang C, Li L. Shade-induced stem elongation in rice seedlings: implication of tissue-specific phytohormone regulation. J Integr Plant Biol. 2016;58:614-7.

86. Li M, Xu W, Yang W, Kong Z, Xue Y. Genome-wide gene expression profiling reveals conserved and novel molecular functions of the stigma in rice. Plant Physiol. 2007;144:1797-812.

87. Singh AK, Kumar R, Tripathi AK, Gupta BK, Pareek A, Pareek SS. Genome-wide investigation and expression analysis of sodium/calcium exchanger gene family in rice and Arabidopsis. Rice. 2015;8:54.

88. Gu L, Wu Y, Jiang M, Si W, Zhang X, Tian D, et al. Dissimilar manifestation of heterosis in superhybrid rice at early-tillering stage under nutrient-deficient and nutrient-sufficient condition. Plant Physiol. 2016;172:1142-53.

89. Xu W, Yang R, Li M, Xing Z, Yang W, Chen G, et al. Transcriptome phase distribution analysis reveals diurnal regulated biological processes and key pathways in rice flag leaves and seedling leaves. PLoS One. 2011;6:e17613.

90. Fujita M, Horiuchi Y, Ueda Y, Mizuta Y, Kubo T, Yano K, et al. Rice expression atlas in reproductive development. Plant Cell Physiol. 2010:51:2060-81.

91. Xing MO, Zhang YJ, Zhou SR, Hu WY, Wu XT, Ye YJ, et al. Global analysis reveals the crucial roles of DNA methylation during rice seed development. Plant Physiol. 2015;168:1417-32.

92. Ouyang Y, Huang X, Lu Z, Yao J. Genomic survey, expression profile and co-expression network analysis of OsWD40 family in rice. BMC Genomics. 2012;13:100

93. Narsai R, Secco D, Schultz MD, Ecker JR, Lister R, Whelan J. Dynamic and rapid changes in the transcriptome and epigenome during germination and in developing rice (Oryza sativa) coleoptiles under anoxia and re-oxygenation. Plant J. 2017:89:805-24.

94. Galbiati F, Chiozzotto R, Locatelli F, Spada A, Genga A, Fornara F. Hd3a, RFT1 and Ehd1 integrate photoperiodic and drought stress signals to delay the floral transition in rice. Plant Cell Environ. 2016;39:1982-93.

95. Yoo YH, Anil K, Chandran N, Park JC, Gho YS, Lee SW, et al. OsPhyB-mediating novel regulatory pathway for drought tolerance in rice root identified by a global RNA-Seq transcriptome analysis of rice genes in response to water deficiencies. Front Plant Sci. 2017;8:580.

96. Krishnan A, Gupta C, Ambavaram MMR, Pereira A. RECoN: rice environment coexpression network for systems level analysis of abiotic-stress response. Front Plant Sci. 2017;8:1640.

97. Ding $X, L i X$, Xiong L. Insight into differential responses of upland and paddy rice to drought stress by comparative expression profiling analysis. Int J Mol Sci. 2013;14:5214-38. 
98. Huang L, Zhang F, Zhang F, Wang W, Zhou Y, Fu B, et al. Comparative transcriptome sequencing of tolerant rice introgression line and its parents in response to drought stress. BMC Genomics. 2014;15:1026.

99. Fu J, Wu H, Ma S, Xiang D, Liu R, Xiong L. OsJAZ1 attenuates drought resistance by regulating JA and ABA signaling in rice. Front Plant Sci. 2017;8:2108.

100. Wang D, Pan Y, Zhao X, Zhu L, Fu B, LiZ. Genome-wide temporal-spatial gene expression profiling of drought responsiveness in rice. BMC Genomics. 2011:12:149.

101. Vasumathy SK, Peringottillam M, Sundaram KT, Kumar SHK, Alagu M. Genome- wide structural and functional variant discovery of rice landraces using genotyping by sequencing. Mol Biol Rep. 2020;47:7391-402.

102. Mishra P, Sinha AK. Rice diversity in Bankura district of West Bengal (India). Biosci Discov. 2012;3:284-7.

103. Manilal KS. Ethnobotany of the rices of Malabar. Contribution to Indian Ethnobotany, Botanical Survey of India, Calcutta; 1990. p. 243-53.

104. Sellamuthu R, Liu GF, Ranganathan CB, Serraj R. Genetic analysis and validation of quantitative trait loci associated with reproductive-growth traits and grain yield under drought stress in a doubled haploid line population of rice (Oryza sativa L.). Field Crop Res. 2011:124:46-58.

105. Gomez SM, Boopathi NM, Kumar SS, Ramasubramanian T, Chengsong Z, Jeyaprakash P, et al. Molecular mapping and location of QTLs for droughtresistance traits in indica rice (Oryza sativa L.) lines adapted to target environments. Acta Physiol Plant. 2010;32:355-64.

106. Pradeepa N, Priya PS, Prince SJ, Kavitha S, Poornima R, Prabhakar MS, et al. In silico analysis of a consensus QTL for drought resistance in rice. Online J Bioinformatics. 2012:13:1-13.

107. Tanksley SD, McCouch SR. Seed banks and molecular maps: unlocking genetic potential from the wild. Science. 1997;277:1063-6.

108. Prince SJ, Vuong TD, Wu X, Bai Y, Lu F, Kumpatla SP, et al. Mapping quantitative trait loci for soybean seedling shoot and root architecture traits in an inter-specific genetic population. Front Plant Sci. 2020;11:1284.

109. McNeece BT, Bagherzad L, Carter TE Jr, Mian MAR. Registration of USDAN7004 soybean germplasm with good yield, elevated seed protein, and 25\% exotic pedigree from Tamahikari. J Plant Registrations. https://doi. org/10.1002/plr2.20039.

110. Liang $\mathrm{H}$, Yu, , Yang $\mathrm{H}, \mathrm{Xu} \mathrm{L}$, Dong $W$, Du H, et al. Inheritance and QTL mapping of related root traits in soybean at the seedling stage. Theor Appl Genet. 2014;127:2127-37.

111. Shomura A, Izava T, Ebana K, Ebitani T, Kanegae H, Konishi S, et al. Deletion in a gene associated with grain size increased yields during rice domestication. Nat Genet. 2008:40:1023-8.

112. Thurber CS, Reagon M, Gross B, Olsen KM, Jia Y, Caicedo AL. Molecular evolution of shattering loci in U.S. weedy rice. Mol Ecol. 2010;19:3271-84.

113. Biscarini F, Cozzi P, Casella L, Riccardi P, Vattari A, Orasen G, et al. Genomewide association study for traits related to plant and grain morphology, and root architecture in temperate rice accessions. PLoS One. 2016;11:e0155425.

114. Deshmukh V, Mankar SP, Muthukumar C, Divahar P, Bharathi A, Thomas $\mathrm{HB}$, et al. Genome-wide consistent molecular markers associated with phenology, plant production and root traits in diverse rice accessions under drought in rainfed target populations of the environment. Curr Sci. 2018:114:329-40.

115. Agnieszka $D$, Boris $P$, Hans $M$, Tom B. Exploiting natural variation in root system architecture via genome-wide association studies. J Exp Bot. 2020;71:2379-89.

116. Gifford ML, Banta JA, Katari MS, Hulsmans J, Chen L, Ristova D, et al. Plasticity regulators modulate specific root traits in discrete nitrogen environments. PLoS Genet. 2013;9:e1003760.

117. Rosas U, Cibrian-Jaramillo A, Ristova D, Banta JA, Gifford ML, Fan AH, et al. Integration of responses within and across Arabidopsis natural accessions uncovers loci controlling root systems architecture. Proc Nat Acad Sci. 2015;112:E2555
118. Zhao K, Tung CW, Eizenga GC, Wright MH, Ali ML, Price AH, Norton GJ, Rafi qul Islam M, Reynolds A, Mezey J, McClung AM, Bustamante CD, McCouch SR. Genome-wide association mapping reveals a rich genetic architecture of complex traits in Oryza sativa. Nat Commun 2011;2:1-10.

119. Phung NTP, Mai CD, Hoang GT, Truong HTM, Lavarenne J, Gonin M, et al. Genome-wide association mapping for root traits in a panel of rice accessions from Vietnam. BMC Plant Biol. 2016;16:64.

120. Sripongpangkul K, Posa GBT, Senadhira DW, Brar D, Huang N, Khush GS, et al. Genes/QTLs affecting flood tolerance in rice. Theor Appl Genet. 2000;101:1074-81.

121. Garrity DP,O'Toole JC. Selection for reproductive stage drought avoidance in rice, using infrared thermometry. Agron J. 1995;87:773-9.

122. Blum A, Ebercon A. Cell membrane stability as a measure of drought and heat tolerance in wheat. Crop Sci. 1981;21(1):43-7.

123. Turner NC. Techniques and experimental approaches for the measurement of plant water status. Plant Soil. 1981;58:339-66.

124. Hiscox J, Israelstam G. A method for the extraction of chlorophyll from leaf tissue without maceration. Can J Bot. 1979;57:1332-4.

125. Fisher RA, Maurer R. Drought resistance in spring wheat cultivars. I. Grain yield responses in spring wheat. Aust J Agric Sci. 1978;29:892-912.

126. O'Leary M. Carbon isotope fractionation in plant. Photochem. 1981:553-67.

127. Sambrook J, Russell D. Molecular cloning, 2000; 3-volume set: a laboratory manual. New York: Cold Spring Harbor; 2001.

128. Pritchard JK, Stephens M, Donnelly P. Inference of population structure using multilocus genotype data. Genetics. 2000;155:945-59.

129. Earl D, VonHoldt B. Conservation genet; 2012. p. 359-61.

130. Yu J, Buckler ES. Genetic association mapping and genome organization of maize. Curr Opin Biotechnol. 2006;17:155-60.

131. Edwards JD, Baldo AM, Mueller LA. Ricebase: a breeding and genetics platform for rice, integrating individual molecular markers, pedigrees and whole-genome-based data. Database. 2016. https://doi.org/10.1093/ database/baw107.

132. Mansueto L, Fuentes RR, Borja FN, Detras J, Abriol-Santos JM, Chebotarov D, et al. Rice SNP-seek database update: new SNPS, indels, and queries. Nucleic Acids Res. 2016:45:D1075-81.

133. Deshmukh R, Singh A, Jain N, Anand S, Gacche R, Singh A, et al. Identification of candidate genes for grain number in rice. Funct Integr Genomics. 2010:3:339-47.

134. Vikram P, Swamy BM, Dixit S, Ahmed HU, Sta Cruz MT, Singh AK, et al. qDTY1.1, a major QTL for rice grain yield under reproductive-stage drought stress with a consistent effect in multiple elite genetic backgrounds. BMC Genet. 2011;12:89.

135. Rao IS, Neeraja CN, Srikanth B, Subrahmanyam D, Swamy KN, Rajesh K, et al. Identification of rice landraces with promising yield and the associated genomic regions und er low nitrogen. Sci Rep. 2018;8:9200.

136. Zimmermann P, Bleuler S, Laule O, Martin F, Ivanov NV, Campanoni P, et al. Expression data-a public resource of high quality curated datasets representing gene expression across anatomy, development and experimental conditions. BioData Mining. 2014;7:1-11.

137. Latha M, Abraham Z, Nair RA, Mani S, Dutta M. Rice landraces of Kerala state of India: a documentation. Int J Biodivers Conserv. 2013;5:250-63.

138. Lyu J, Zhang S, Dong Y, He W, Zhang J, Deng X, et al. Analysis of elite variety tag SNPs reveals an important allele in upland rice. Nat Commun. 2013;4:2138.

\section{Publisher's Note}

Springer Nature remains neutral with regard to jurisdictional claims in published maps and institutional affiliations. 